\title{
Hymenophyllaceae (Polypodiopsida) na Mesorregião Metropolitana de Belém, Estado do Pará, Brasil ${ }^{1}$
}

Hymenophyllaceae (Polypodiopsida) from the Metropolitan Mesoregion of Belém, State of Pará, Brazil

\author{
Gisele Teixeira $^{2,4}$ \& Marcio Roberto Pietrobom ${ }^{3}$
}

\begin{abstract}
Resumo
Hymenophyllaceae (Polypodiopsida) na Mesorregião Metropolitana de Belém, estado do Pará, Brasil. No Brasil, bem como na Amazônia brasileira, a maioria das informações referentes a Hymenophyllaceae está contida em inventários florísticos, sendo escassos os estudos específicos para esta família. Este trabalho apresenta o tratamento florístico de Hymenophyllaceae na Mesorregião Metropolitana de Belém. Foram registradas 19 espécies distribuídas entre os gêneros Didymoglossum (6 spp.), Hymenophyllum (3 spp.), Polyphlebium (1 sp.) e Trichomanes ( 9 spp.), o que representa cerca de $60 \%$ das himenofiláceas do Pará. As espécies Trichomanes crispum e Trichomanes vittaria constituem novos registros para a área de estudo. Os municípios de Belém e Santa Barbara do Pará contabilizaram maior riqueza específica, provavelmente em decorrência dos parques ecológicos e da concentração de coletas nessas áreas. São apresentadas chaves para identificação de gêneros e espécies, bem como descrições, comentários taxonômicos, dados de distribuição geográfica, tipo de vegetação, substrato e ilustrações.
\end{abstract}

Palavras-chave: Amazônia brasileira, samambaias, Didymoglossum, Trichomanes.

\begin{abstract}
Hymenophyllaceae (Polypodiopsida) from the Metropolitan Mesoregion of Belém, State of Pará, Brazil. In Brazil as well as in the Brazilian Amazon, most information regarding to Hymenophyllaceae is contained in floristic surveys and there are few specific studies to the family. This work presents a floristic treatment of filmy ferns from Metropolitan Mesoregion of Belem. We recorded 19 species belonging to the genera Didymoglossum (6 spp.), Hymenophyllum (3 spp.), Polyphlebium (1 sp.) and Trichomanes (9 spp.) that correspond to about $60 \%$ of filmy ferns from Pará. Trichomanes crispum and T. vittaria are new records to the studied area. The cities of Belém and Santa Barbara do Pará have greater species richness probably due to the ecological parks and to concentrate studies in these areas. Keys to the genera and species as well as descriptions, taxonomic comments, geographic distributions data, types of vegetation, substratum and illustrations are given. Key words: Brazilian Amazon, ferns, Didymoglossum, Trichomanes.
\end{abstract}

\section{Introdução}

Hymenophyllaceae está posicionada na classe Polypodiopsida, ordem Hymenophyllales e compreende nove gêneros e cerca de 600 espécies (Smith et al. 2006). É a família mais diversa dentre as samambaias leptosporangiadas basais em termos de riqueza de espécies, morfologia e ecologia, cujos membros são caracterizados pela lâmina em geral extremamente fina e desprovida de estruturas que regulem a perda de água e são restritos a ambientes úmidos (Dubuisson et al. 2011).

A circunscrição dos gêneros foi por muito tempo motivo de debates. Na classificação tradicional adotada por Tryon \& Tryon (1982), a família consistia de apenas dois gêneros: Hymenophyllum Sm. e Trichomanes L. Outros

\footnotetext{
${ }^{1}$ Parte integrante da dissertação de Mestrado do primeiro autor

${ }^{2}$ Museu Paraense Emílio Goeldi - MCT, Campus de Pesquisa, Coordenação de Botânica, Av. Perimetral 1901, 66017-970 ,Terra Firme, Belém, PA, Brasil.

${ }^{3}$ Universidade Federal do Pará - MEC. Campus de Bragança, Instituto de Estudos Costeiros, Alameda Leandro Ribeiro s/n, 6860000, Aldeia, Bragança, PA, Brasil.

${ }^{4}$ Autor para correspondência: giseleteixeira.bio@gmail.com
} 
sistematas propuseram um maior numero de gêneros: Morton (1968) estabeleceu 4 gêneros; Iwatsuki (1977), 8 gêneros; Copeland (1938), 34 gêneros; e Pichi-Sermolli (1977), 47 gêneros.

Estudos filogenéticos posteriores (Pryer et al. 2001; Ebihara et al. 2006) indicaram dois amplos clados como suporte para o sistema tradicional adotado por Tryon \& Tryon (1982), mas com algumas modificações. O clado himenofilóide manteve as espécies no gênero Hymenophyllum, incluindo algumas antes pertencentes a Trichomanes, e o clado tricomanóide incluiu vários grupos monofiléticos, que foram reconhecidos como gêneros distintos.

A revisão proposta por Ebihara et al. (2006) reorganizou os gêneros de Hymenophyllaceae, mantendo as espécies da linhagem himenofilóide dentro de Hymenophyllum e subdividindo a linhagem tricomanóide em oito gêneros correspondentes aos clados gerados pela análise molecular [Crepidomanes (C. Presl) C. Presl, Vandenboschia Copel., Didymoglossum Desv., Polyphlebium Copel., Callistopteris Copel., Trichomanes, Abrodictyum C. Presl e Cephalomanes C. Presl]. Esse sistema, baseado em dados moleculares e morfológicos, permitiu um delineamento mais consistente para a família a nível genérico.

No Brasil, estudos específicos para a família se resumem aos de Sehnem (1971) e Windisch (1988, 1992, 1996), com base no sistema tradicional e os mais recentes realizados por Hirai \& Prado (2011) e Cunha et al. (2014) embasados na classificação de Ebihara et al. (2006). Na Amazônia brasileira, onde ocorrem 60 das 87 espécies registradas para o Brasil (Windisch 2014), há apenas de um estudo realizado por Windisch (1988) sobre espécies do complexo Trichomanes crispum L. Para o estado do Pará ainda não foi desenvolvido um estudo especifico.

No Pará, Hymenophyllaceae está entre as famílias mais representativas nos inventários realizados (ex. Costa \& Pietrobom 2007, 2010) e muitos destes contribuíram com novos registros para o Estado, para a região Amazônica e para o Brasil (Costa et al. 2006; Costa \& Pietrobom 2007, 2010; Goés-Neto \& Pietrobom 2012). A Mesorregião Metropolitana de Belém (MMB) é uma das áreas que concentra a maior parte dos estudos florísticos no Estado e que muito contribuiu para as novas referencias citadas acima. No entanto, ainda existem municípios dentro da MMB que representam lacunas ao conhecimento desse grupo.
O objetivo do presente estudo foi realizar o tratamento florístico das espécies de Hymenophyllaceae ocorrentes na Mesorregião Metropolitana de Belém e teve por finalidade gerar uma base de consulta mais sólida para identificação de espécies de Hymenophyllaceae não só a nível local bem como para a região amazônica e fornecer subsídios para estudos nas mais diversas áreas.

\section{Material e Métodos}

Localização e caracterização da área de estudo

A Mesorregião Metropolitana de Belém abrange os municípios de Ananindeua, Barcarena, Belém, Benevides, Bujaru, Castanhal, Inhangapi, Marituba, Santa Bárbara do Pará, Santa Izabel do Pará e Santo Antônio do Tauá.

O clima na MMB é equatorial úmido com temperatura média de $25-26^{\circ} \mathrm{C}$ e umidade relativa em torno de $85 \%$. O regime pluviométrico varia, com média de 2.350-2.500 mm/ano, com chuvas intensas no começo do ano. O relevo faz parte do Planalto Rebaixado da Amazônia com a maioria dos municípios apresentando topografia relativamente uniforme e níveis pouco elevados. Os solos apresentam elevada acidez e baixa fertilidade (IDESP 2013).

A vegetação é composta principalmente por florestas secundárias e/ou capoeiras em vários estágios, que substituíram as florestas primárias densas dos baixos platôs em razão do desmatamento. Porém, ainda podem ser encontradas áreas de floresta primária preservada em alguns municípios. Nos trechos sob influência de inundações são encontradas florestas ciliares, de várzea e matas de galeria, ocorrendo também o mangue em algumas áreas (IDESP 2013).

Amostragem e tratamento dos dados

O estudo foi baseado em material herborizado depositado nas coleções dos herbários do Museu Paraense Emílio Goeldi (MG), da Embrapa Amazônia Oriental (IAN), e em material proveniente de coletas realizadas nos municípios pertencentes à área de estudo. A coleta e herborização do material seguiram as técnicas descritas por Bridson \& Forman (1998) e as amostras foram incorporadas ao acervo do herbário MG com envio de duplicatas para os herbários HBRA e IAN, siglas segundo o Index Herbariorum (Thiers 2012).

O material botânico foi identificado a partir de bibliografia específica para a família e gêneros, 
e por comparações com exsicatas depositadas nos herbários MG e IAN. O sistema de classificação adotado foi o proposto por Ebihara et al. (2006). Os nomes dos autores dos táxons estão abreviados de acordo com o Internacional Plant Name Index (IPNI 2014).

Foram elaboradas chaves de identificação para gêneros e espécies, além de descrições para a família, gêneros e espécies, ilustrações, comentários taxonômicos e informações a respeito dos substratos e do tipo de vegetação em que as espécies ocorrem. Os tipos de formas de vida adotados foram os utilizados por Zuquim et al. (2008) e o tipo de vegetação está baseado em Pires (1973).

Os dados referentes à distribuição das espécies foram retirados de Lellinger (1994), Pacheco (1995), Smith (1995) e Mickel \& Smith (2004). A distribuição no Brasil teve como referência a Lista de Espécies da Flora do Brasil (Windisch 2014), o material testemunho depositado nos herbários visitados (BHCB, HB, MG, RB e SP) e em dados de levantamentos florísticos (Tryon \& Conant 1975; Costa et al. 2006; Pietrobom \& Barros 2006; Costa \& Pietrobom 2007, 2010; Maciel et al. 2007; Fernandes et al. 2012; GoésNeto \& Pietrobom 2012).

\section{Resultados e Discussão}

Hymenophyllaceae está representada na Mesorregião Metropolitana de Belém por 19 espécies, o que corresponde a cerca de 60\% das himenofiláceas registradas para o Estado do Pará (Windisch 2014). Essas espécies estão distribuídas em quatro gêneros, a saber: Trichomanes (9 spp.), Didymoglossum (6 spp.), Hymenophyllum (3 spp.) e Polyphlebium (1 espécie). As espécies Trichomanes crispum L. e Trichomanes vittaria DC. ex Poir. constituem novos registros para a área de estudo.

A maioria das espécies apresenta formas de vida epifíticas (13 epífitas e duas hemiepífitas) e utilizam como principais substratos troncos vivos e em decomposição, sendo que grande parte apresenta especificidade por um ou outro substrato. As espécies terrestres (5) ocorreram sobre barrancos e/ou próximo a cursos de água. De uma forma geral, as espécies não foram exclusivas quanto ao tipo de vegetação.

Com relação ao padrão de distribuição geográfica, as espécies são neotropicais, exceto $H$. polyanthos (Sw.) Sw., que ocorre também em algumas regiões tropicais da África e Ásia (Mickel \& Smith 2004). A maioria das espécies encontradas (10 spp.) se distribui pelos domínios brasileiros Amazônia e Floresta Atlântica, quatro são encontradas também no Cerrado brasileiro e cinco são registradas apenas para Amazônia ( $D$. ekmanii, D. pinnatinervium, T. ankersii, T. trollii e $T$. vittaria).

Os municípios de Belém e Santa Barbara do Pará contabilizaram maior riqueza específica (16 spp.), provavelmente associada aos parques ecológicos presentes nesses municípios como, por exemplo, o Parque Ambiental de Belém e o Parque Ecológico do Gunma. Esses parques são relativamente isolados do centro urbano e apresentam vegetação em boas condições de conservação em relação às demais áreas verdes protegidas dentro da Região Metropolitana de Belém (Costa \& Pietrobom 2010; Ferreira et al. 2012). Além do mais, esses parques fazem parte das poucas áreas verdes ainda preservadas da MMB, o que por sua vez, também explicaria a grande representatividade de espécies nessas áreas. Ressalta-se ainda a importância dos mesmos pelo registro de espécies escassas nas coleções como Didymoglossum ekmanii, Hymenophyllum abruptum e Trichomanes crispum.

\section{Hymenophyllaceae}

Plantas epífitas, hemiepífitas e terrestres. Caule curto a longo-reptante, decumbente ou ascendente, subereto a ereto, com tricomas e raízes, ou ainda, raízes verdadeiras ausentes (neste caso, densamente coberto por tricomas rizoidais). Frondes espaçadas, aproximadas (imbricadas ou não) ou fasciculadas, monomorfas, subdimorfas ou acentuadamente dimorfas; pecíolo alado ou não, glabro ou piloso; lâmina simples, pinatífida, pinatissecta, pinado-pinatífida a mais dividida, de formato variável, margem inteira, levemente crispada a crenada, glabra ou pilosa, superfície laminar geralmente glabra; venação furcada, flabelada ou pinada, podendo apresentar ou não nervura marginal coletora, falsa vênula submarginal e falsas vênulas entre as verdadeiras. Soros um a vários, no ápice dos segmentos ou nas terminações das vênulas laterais, podendo estar dispostos somente no lado acroscópico, em ambos os lados ou ainda ao longo da margem; indúsio bivalvar ou tubular, livre, parcialmente ou totalmente imerso no tecido laminar, glabro ou piloso. 


\section{Chave de identificação para os gêneros de Hymenophyllaceae da MMB}

1. Venação furcada, ápice dos segmentos emarginado.

2. Indúsio bivalvar; receptáculo geralmente não projetado além das bordas do indúsio

2’. Indúsio tubular; receptáculo geralmente longamente exserto Hymenophyllum

1'. Venação pinada ou flabelada; ápice dos segmentos não emarginado.

3. Raízes ausentes; frondes até $2,5 \mathrm{~cm}$ compr. aproximadamente; falsas vênulas presentes e paralelas às vênulas verdadeiras (exceto em $D$. pinnatinervium) Didymoglosssum

3'. Raízes presentes e robustas; frondes usualmente maiores que $5 \mathrm{~cm}$ compr.; falsas vênulas ausentes, ou, se presentes, perpendiculares às vênulas verdadeiras Trichomanes

Didymoglossum Desv., Mém. Soc. Linn. Paris 6: 330. 1827.

Plantas epífitas. Caule longo-reptante, filiforme, densamente coberto por tricomas rizoidais, raízes ausentes. Frondes espaçadas ou imbricadas, monomorfas ou subdimorfas; pecíolo alado ou não, com tricomas rizoidais; lâmina simples a 1-2-pinatífida, de formato variável, margem inteira a crenada, glabra ou pilosa, superfície laminar glabra ou com tricomas somente na base; venação pinada ou flabelada, falsas vênulas geralmente presentes entre as verdadeiras, presença ou não de uma falsa vênula submarginal, sem vênula marginal coletora. Soros no ápice da lâmina; indúsio tubular, campanulado, livre ou imerso no tecido laminar, bilabiado ou não, lábios apresentando ou não fileiras de células marginais escurecidas; receptáculo exserto.

Gênero pantropical com dois subgêneros e cerca de 30 espécies (Ebihara et al. 2006). No Brasil ocorrem 13 espécies e no estado do Pará se tem registro de oito espécies (Windisch 2014). Na área de estudo foram registradas seis espécies.

Didymoglossum é representado por plantas epífitas com caule filiforme sem raízes verdadeiras, sendo fortemente aderido ao forófito por meio de tricomas rizoidais. A lâmina é diminuta e geralmente inteira com muitas falsas vênulas longitudinais (Boer 1962).

\section{Chave de identificação para as espécies de Didymoglossum da MMB}

1. Margem da lâmina glabra; falsa vênula submarginal presente.

2. Falsa vênula submarginal contínua.....

2. Didymoglossum ekmanii

2. Falsa vênula submarginal interrompida 3. Didymoglossum kapplerianum

1'. Margem da lâmina pilosa; falsa vênula submarginal ausente.

3. Margem da lâmina apenas com tricomas simples e/ou bífidos, nunca estrelados; lábios do indúsio sem fileiras de células marginais escurecidas .... 5. Didymoglossum pinnatinervium

3'. Margem da lâmina com tricomas estrelados (podendo ainda ocorrer tricomas simples e bífidos); lábios do indúsio com uma ou mais fileiras de células marginais escurecidas.

4. Lâmina 1-2-pinatífida; margem com tricomas bífidos, simples e estrelados; falsas vênulas próximas a margem da lâmina 4. Didymoglossum krausii

4'. Lâmina simples; margem apenas com tricomas estrelados; falsas vênulas ao longo da lâmina.

5. Venação pinada; vena principal evidente, percorrente até o ápice da lâmina; lábios do indúsio com 1 fileira de células marginais escurecidas

1. Didymoglossum angustifrons

5'. Venação flabelada; vena principal não evidente ou não se estendendo além da porção mediana da lâmina; lábios do indúsio com várias fileiras de células marginais escurecidas 6. Didymoglossum punctatum

1. Didymoglossum angustifrons Fee, Mém. Foug. 11: 113, t. 28, f. 5.1866.

Fig. $1 \mathrm{a}-\mathrm{c}$

Frondes $0,4-1,5 \mathrm{~cm}$ compr. $\times 0,2-0,4 \mathrm{~cm}$ larg., espaçadas ou imbricadas, monomorfas ou subdimorfas; pecíolo 0,1-0,4 cm compr., alado, com tricomas rizoidais no eixo e tricomas estrelados na ala; lâmina simples, ovada, linear a linear-oblonga, podendo ser pinatilobada no ápice, 
ou ainda orbicular, a maioria em frondes estéreis, margem inteira com tricomas estrelados, superfície laminar glabra; venação pinada, vena principal evidente, percorrente até o ápice da lâmina, falsas vênulas presentes, paralelas às verdadeiras, falsa vênula submarginal ausente. Soros até 5 por fronde, apicais nos lobos; indúsio imerso no tecido laminar até os lábios, ápice expandido, bilabiado, glabro, lábios com uma fileira de células marginais escurecidas.

Material selecionado: Belém, Ilha de Mosqueiro, 18.V.2005, J.M. Costa \& M.R. Pietrobom 166 (MG); Bujaru, Vila Ponta de Terra, 14.VIII.2012, G. Teixeira \& M.R. Pietrobom 200 (MG); Castanhal, estrada para o rio Apeú, 20.VIII.2012, G. Teixeira \& M.R. Pietrobom 216 (MG); Inhangapi, Vila Jundiaí, Balneário Água Preta, 09.II.2012, G. Teixeira \& M.R. Pietrobom 179 (MG); Santa Barbara do Pará, Parque Ecológico do Gunma, 13.V.2005, M.R. Pietrobom 5950 (MG); Santa Izabel do Pará, Vila Caraparu, 07.II. 2012, G. Teixeira \& M.R. Pietrobom 163 (MG).

Didymoglossum angustifrons se assemelha à forma pinada de $D$. ovale E. Fourn., uma espécie também registrada no Pará, mas distingue-se por apresentar indúsio imerso no tecido laminar até os lábios e apenas uma fileira de células escurecidas no bordo do indúsio, enquanto $D$. ovale apresenta indúsio parcialmente imerso e com duas ou mais fileiras de células marginais escurecidas (Boer 1962).

Espécie neotropical com ocorrência no México, Guatemala, Costa Rica, Grandes Antilhas, Trinidad, Guiana, Guiana Francesa, Suriname, Venezuela, Colômbia, Equador, Peru, Bolívia e Paraguai. No Brasil ocorre nos domínios Amazônia e Floresta Atlântica (RR, AP, AM, PA, RO, MT, CE, PE, BA, RJ, SP, PR, SC e RS). Na MMB foi registrada sobre troncos vivos (preferencialmente) ou em decomposição em matas de terra firme, igapó e várzea.

2. Didymoglossum ekmanii (Wess. Boer) Ebihara \& Dubuisson, Blumea 51(2): 236. 2006.

Fig. 1d-e

Frondes $0,9-2,2 \mathrm{~cm}$ compr. $\times 0,4-0,8 \mathrm{~cm}$ larg., espaçadas ou imbricadas, monomorfas ou subdimorfas; pecíolo 0,2-0,4 cm compr., estreitamente alado ou não, com tricomas rizoidais; lâmina simples, geralmente a estéril ovada ou obovada, a fértil ovada a oblonga, margem inteira, glabra, superfície laminar glabra; venação pinada, flabelada nas estéreis, vena principal percorrente até o ápice da lâmina ou não, às vezes se divide na parte superior da lâmina para formar duas ou mais vênulas, falsas vênulas presentes, paralelas às verdadeiras, falsa vênula submarginal presente e contínua. Soros 1-4 por fronde, apicais; indúsio totalmente imerso no tecido laminar, ápice expandido, não bilabiado, glabro, sem fileiras de células marginais escurecidas.

Material examinado: Santa Barbara do Pará, Parque Ecológico do Gunma, 09.VII.2008, M.R. Pietrobom et al. 7731 (MG).

Material adicional: BRASIL. AMAZONAS: estrada Manaus-Caracarai, 27.IX.1973, C.C. Berg et al. 18149 (HB); BRASIL. PARÁ: Alenquer, Floresta Estadual do Paru, 11.XII.2008, S. Maciel 1536 (MG); COLÔMBIA. CHOCÓ: Cabita Bay, 13.II.1934, W.R. Taylor 1267 (RB).

Didymoglossum ekmanii é morfologicamente muito semelhante a $D$. kapplerianum, sendo facilmente confundidas. Boer (1962) descreveu pela primeira vez $D$. ekmanii e a distinguiu de D. kapplerianum por apresentar falsa vênula submarginal contínua e pelo formato cúbico das células externas a essa falsa vênula. Segundo esse autor, em $D$. kapplerianum a falsa vênula não é contínua (apresenta interrupções ao longo da lâmina) e as células externas são alongadas. Porém, no material em análise, o formato das células externas variou entre os espécimes e mesmo ao longo de uma mesma lamina foliar, sendo possível distingui-las apenas pela falsa vênula submarginal.

Espécie neotropical ocorrendo no México, Belize, Honduras, Costa Rica, Panamá, Cuba, Guiana, Guiana Francesa, Suriname, Venezuela, Colômbia, Equador, Peru e Bolívia. No Brasil, a espécie é restrita à Amazônia, ocorrendo no AM, PA, AC e RO. Na MMB foi registrada sobre tronco vivo em mata de terra firme.

3. Didymoglossum kapplerianum (Sturm) Ebihara \& Dubuisson, Blumea 51(2): 236. 2006.

Fig. 1f-g

Frondes $0,7-1,3 \mathrm{~cm}$ compr., $0,4-0,7 \mathrm{~cm}$ larg., espaçadas ou imbricadas, monomorfas ou subdimorfas; pecíolo 0,1-0,3 cm compr., não ou estreitamente alado, com tricomas rizoidais; lâmina simples, geralmente a estéril cordada ou oblonga, a fértil oblonga ou ovada a obovada, margem inteira, glabra, superfície laminar glabra; venação pinada, flabelada nas estéreis, vena principal percorrente até o ápice da lâmina ou não, às vezes se divide na parte superior da lâmina para formar duas ou mais vênulas, falsas vênulas presentes e paralelas às verdadeiras, falsa vênula submarginal presente, porém descontínua, interrompida. Soros 
1-5 por fronde, apicais; indúsio totalmente imerso no tecido laminar, ápice expandido, não bilabiado, glabro, sem fileiras de células marginais escurecidas.

Material selecionado: Belém, Ilha de Mosqueiro, 29.IX.2005, J.M. Costa \& M.R. Pietrobom 306 (MG); Bujarú, Vila Ponta de Terra, 14.VIII. 2012, G. Teixeira \& M.R. Pietrobom 197 (MG); Santa Barbara do Pará, Parque Ecológico do Gunma, 17.V.2005, M.R. Pietrobom 5988 (MG); Santo Antônio do Tauá, RPPN Klagesi, 11.IV.2007, R.S. Tavares 24 (MG).

Material adicional: GUIANA FRANCESA. Route Régina-Saint Georges: Bassin du Ba, 7.IV.1991, G. Cremers \& S. Gautier 12024 (HB).

Didymoglossum kapplerianum é muito semelhante a $D$. ekmanii, sendo facilmente confundidas (ver comentário em D. ekmanii). O padrão contínuo da falsa vênula submarginal é uma característica de difícil visualização, o que por muitas vezes torna duvidosa a determinação dessas espécies.

Espécie neotropical ocorrendo na Costa Rica, Panamá, Porto Rico, Trinidad, Guiana, Guiana Francesa, Suriname, Venezuela, Colômbia, Equador e Peru. No Brasil ocorre nos domínios Amazônia e Floresta Atlântica (AP, AM, PA, RJ e SP). Na MMB foi registrada em troncos vivos (geralmente na base do tronco) em matas de terra firme e igapó.

4. Didymoglossum krausii (Hook. \& Grev.) C. Presl, Hymenophyllaceae 115. 1843. Fig. 1h-i

Frondes 1-2,2 cm compr. $\times 0,4-1,1 \mathrm{~cm}$ larg., espaçadas, monomorfas; pecíolo 0,1-0,4 cm compr., não alado, com tricomas rizoidais; lâmina 1-2-pinatífida, oblonga a oblongo-lanceolada, com tricomas estrelados evidentes nos enseios dos segmentos, margem levemente ondulada com tricomas bífidos, simples e estrelados, superfície laminar glabra; venação pinada, vena principal percorrente até o ápice da lâmina, falsas vênulas esparsas, paralelas, próximas à margem da lâmina, falsa vênula submarginal ausente. Soros 1-8(-12) por fronde, apicais nos lobos ou segmentos, geralmente na parte superior da lâmina; indúsio imerso no tecido laminar até os lábios ou pelo menos alados, ápice expandido, bilabiado, glabro, lábios com 1 ou mais fileiras de células marginais escurecidas.

Material examinado: Belém, Bosque Rodrigues Alves, 25.V.2004, S.M. Rosario \& M.R. Pietrobom 54 (IAN); Santo Antônio do Tauá, RPPN Klagesi, 05.XII. 2007, R.S. Tavares 37 (MG).
Didymoglossum krausii difere das demais espécies do gênero que ocorrem na MMB, principalmente pela lâmina 1-2-pinatífida e por apresentar além dos tricomas estrelados, tricomas bífidos e simples na margem da lâmina. É muito semelhante a $D$. reptans (Sw.) C. Presl, sendo distintas apenas pelas falsas vênulas paralelas entre as verdadeiras e o indúsio em geral não imerso nesta última espécie, enquanto que em $D$. krausii as falsas vênulas estão localizadas próximo às margens e o indúsio é imerso no tecido laminar (Mickel \& Smith 2004).

Espécie neotropical ocorrendo no México, Trinidad, Guiana, Guiana Francesa, Venezuela, Colômbia, Equador, Peru, Bolívia, Paraguai e Argentina. No Brasil ocorre nos domínios Amazônia e Floresta Atlântica (AM, AP, PA, AC, RO, MT, MS, PE, AL, MG, ES, RJ, SP, PR, SC e RS). Na MMB foi registrada sobre tronco vivo em matas de terra firme.

5. Didymoglossum pinnatinervium (Jenman) Pic. Serm., Webbia 28:469. 1793.

Fig. 2a-b

Frondes $0,3-0,8 \mathrm{~cm}$ compr. $\times 0,2-0,5 \mathrm{~cm}$ larg., espaçadas ou imbricadas, monomorfas ou subdimorfas; pecíolo até 0,2 cm compr., não alado, com tricomas rizoidais; lâmina simples, geralmente a estéril mais arredondada a orbicular, a fértil ovada a oblongo-ovada, margem inteira com tricomas simples ou geralmente bífidos, base da lâmina com tricomas rizoidais, tomentosos; venação pinada, palmada nas estéreis, vena principal percorrente até o ápice da lâmina, falsas vênulas ausentes, falsa vênula submarginal ausente. Soros 1 por fronde, apicais; indúsio imerso no tecido laminar até os lábios, ápice expandido, não bilabiado, glabro, sem fileiras de células marginais escurecidas.

Material selecionado: Barcarena, Ilha de Trambioca, Comunidade Cuipiranga, 22.IV.2009, G. Teixeira et al 105 (MG); Belém, Ilha de Mosqueiro, 13.IV.2005, J.M. Costa et al. 112 (MG); Bujaru, Vila Ponta de Terra, 14.VIII.2012, G. Teixeira \& M.R. Pietrobom 201 (MG); Castanhal, estrada para o rio Apeú, 20.VIII.2012, G. Teixeira \& M.R. Pietrobom 213 (MG); Santa Barbara do Pará, Parque Ecológico do Gunma, 17.V.2005, M.R. Pietrobom 5989 (MG); Santa Izabel do Pará, Vila de Caraparu, 07.II.2012, G. Teixeira \& M.R. Pietrobom 165 (MG); Santo Antônio do Tauá, RPPN Klagesi, 11.IV.2007, R.S. Tavares 05 (MG).

Didymoglossum pinnatinervium é a única entre as espécies do gênero ocorrentes na área de estudo que possuem margem da lamina pilosa que não apresenta falsas vênulas e nem 

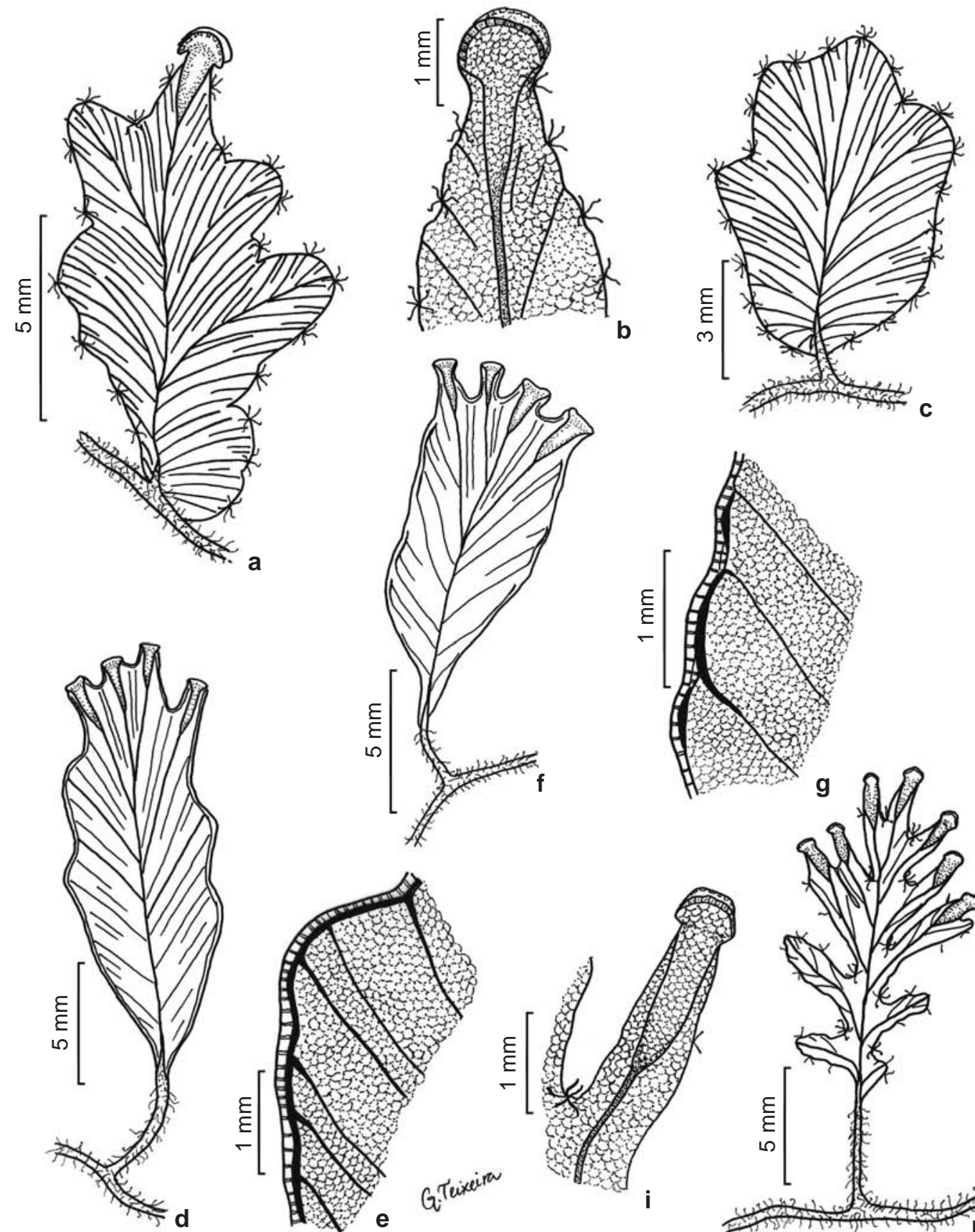

Figura 1 - a-c. Didymoglossum angustifrons (G. Teixeira \& M.R. Pietrobom 168, 175) - a. fronde fértil; b. detalhe do indúsio e da fileira única de células marginais escurecidas; c. fronde estéril. d-e. Didymoglossum ekmanii (M.R. Pietrobom et al. 7731) - d. fronde fértil; e. detalhe da lâmina e da falsa vênula submarginal contínua. f-g. Didymoglossum kapplerianum (J.M. Costa \& M.R. Pietrobom 306) - f. fronde fértil; g. detalhe da lâmina e da falsa vênula submarginal interrompida. h-i. Didymoglossum krausii (S.M. Rosário \& M.R. Pietrobom 54) - h. fronde fértil; i. detalhe da lâmina com tricomas estrelados no enseio do lobo.

Figure 1 - a-c. Didymoglossum angustifrons (G. Teixeira \& M.R. Pietrobom 168, 175) - a. fertile frond; b. detail of the indusium and single row of dark border cells; c. sterile frond. d-e. Didymoglossum ekmanii (M.R. Pietrobom et al. 7731) - d. fertile frond; e. blade detail and continuous submarginal false vein. f-g. Didymoglossum kapplerianum (J.M. Costa \& M.R. Pietrobom 306) - f. fertile frond; g. blade detail and discontinuous submarginal false vein. h-i. Didymoglossum krausii (S.M. Rosário \& M.R. Pietrobom 54) - h. fertile frond; i. blade detail with stellate hairs on the segment bottom. 
margem do indúsio escurecida. Didymoglossum nummularium Bosch é outra espécie que ocorre no domínio amazônico e que não possui células da margem do indúsio escurecidas, mas difere por apresentar os lábios do indúsio distintos e formato da fronde fértil circular (Boer 1962), enquanto que em $D$. pinnatinervium os lábios do indúsio não são distintos e o formato da fronde fértil é oval a oblonga.

Espécie neotropical ocorrendo em Trinidad, Guiana, Guiana Francesa, Suriname e Venezuela. No Brasil a espécie é restrita à Amazônia, sendo citada apenas para o estado do Pará. Na MMB foi registrada sobre troncos vivos em matas de terra firme, igapó e várzea.

6. Didymoglossum punctatum (Poir.) Desv., Mém. Soc. Linn. Paris 6: 330. 1827. Fig. 2c-e

Frondes 0,7-1,7 cm compr. $\times 0,6-1 \mathrm{~cm}$ larg., espaçadas ou imbricadas, monomorfas ou subdimorfas; pecíolo até $0,6 \mathrm{~cm}$ compr., não alado ou estreitamente alado distalmente, com tricomas rizoidais no eixo e tricomas estrelados na ala; lâmina simples, orbicular a ovada, linearoblonga, lobada ou não no ápice, margem inteira ou crenada, com tricomas estrelados, superfície laminar glabra; venação flabelada, vena principal não diferenciada ou não se estendendo além da parte mediana da lâmina, falsas vênulas presentes e paralelas às verdadeiras, falsa vênula submarginal ausente. Soros até 4 por fronde, no enseio dos lobos ou nos lobos; indúsio livre ou somente com a base imersa no tecido laminar, ápice expandido, bilabiado, glabro, lábios com várias fileiras de células marginais escurecidas. Material selecionado: Barcarena, Ilha de Trambioca, Comunidade Arrozal, 5.X.2007, G. Teixeira \& M.R. Pietrobom 11 (MG); Belém, Ilha do Combu, 23.IV.2008, J.M. Costa \& R.S. Fernandes 477 (MG); Benevides, Balneário Bituba, 02.XI. 2011, G. Teixeira \& M.R. Pietrobom 160 (MG); Inhangapi, Balneário Água Preta, 09.II.2012, G. Teixeira \& M.R. Pietrobom 178 (MG); Santa Barbara do Pará, Parque Ecológico do Gunma, 17.V.2005, M.R. Pietrobom 5960 (MG); Santa Izabel do Pará, Vila Caraparu, 07.II.2012, G. Teixeira \& M.R. Pietrobom 164 (MG); Santo Antônio do Tauá, RPPN Klagesi, 11.IV.2007, R.S. Tavares 04 (MG).

Didymoglossum punctatum é semelhante a $D$. angustifrons no formato da lâmina e nos tricomas estrelados da margem, mas difere por apresentar venação flabelada com vena principal não percorrente até o ápice da lâmina e indúsio geralmente livre com várias fileiras de células marginais escurecidas. D. angustifrons apresenta venação pinada com vena principal percorrente até o ápice da lâmina e indúsio imerso no tecido laminar com apenas uma fileira de células marginais escurecidas.

Espécie neotropical ocorrendo nos Estados Unidos da América, Guatemala, Panamá, Guiana, Guiana Francesa, Suriname, Venezuela, Colômbia, Equador, Peru e Bolívia. No Brasil ocorre nos domínios fitogeográficos Amazônia e Floresta Atlântica (AP, AM, PA, AC, RO, MT e RJ, SP, PR e RS). Na MMB foi registrada na base de tronco vivo (preferencialmente) ou em decomposição em matas de terra firme, várzea e igapó.

Hymenophyllum Sm., Mém. Acad. Roy. Sci. (Turin) 5: 418. 1973.

Plantas epífitas. Caule longo-reptante, filiforme, com tricomas e raízes delgadas. Frondes espaçadas, monomorfas; pecíolo alado ou não, glabro ou piloso; lâmina pinado-pinatífida ou mais vezes dividida, de formato variável, margem inteira ou levemente crispada, glabra ou pilosa, superfície laminar glabra; raque alada, glabra ou pilosa; segmentos lineares a oblongos, ápice em geral emarginado; venação furcada acompanhando a dissecção laminar, sem falsas vênulas, falsa vênula submarginal e vênula marginal coletora. Soros apicais nos segmentos; indúsio bivalvar, circular a ovado ou obovado, parcialmente imerso no tecido laminar; receptáculo geralmente não projetado além das bordas do indúsio ou ainda projetando-se um pouco além das bordas em frondes maduras.

Gênero pantropical com 10 subgêneros e cerca de 250 espécies (Ebihara et al. 2006), com algumas ocorrendo em latitudes subtropicais ou temperadas (Windisch 1996). No Brasil ocorrem 31 espécies e no estado do Pará se tem registro de quatro espécies (Windisch 2014). Na área de estudo ocorrem três espécies.

Hymenophyllum é representado por plantas epífitas com caule filiforme apresentando raízes delgadas, lâmina várias vezes dividida e extremamente fina, venação furcada com vênulas seguindo a divisão da lâmina e em geral bem espessas, além do indúsio bivalvar que é único desse gênero. Na classificação de Ebihara et al. (2006), sua circunscrição corresponde a Hymenophyllum no sistema bigenérico (Tryon \& Tryon 1982), além de algumas espécies antes pertencentes a Trichomanes. 


\section{Chave de identificação para as espécies de Hymenophyllum da MMB}

1. Tricomas presentes na margem da lâmina, raque e vênulas 2. Hymenophyllum hirsutum

1'. Tricomas ausentes na margem da lâmina, raque e vênulas

2. Lâmina ternada ou pinado-pinatífida; indúsio obovado.

1. Hymenophyllum abruptum

2'. Lâmina 2-3-pinatífida; indúsio orbicular a oval

3. Hymenophyllum polyanthos

1. Hymenophyllum abruptum Hook., Sp. Fil. 1: 88 (1844).

Fig. 2f-g

Frondes $0,5-1,4 \mathrm{~cm}$ compr. $\times 0,5-0,8 \mathrm{~cm}$ larg., espaçadas, monomorfas; pecíolo $0,2-0,5$ cm compr., não alado, tricomas castanho-escuros, simples, na inserção com o caule; lâmina ternada a pinado-pinatífida, suborbicular, deltóide, ovada a elíptica, margem inteira, glabra, superfície laminar glabro; raque alada, glabra; pinas ca. 3 pares, pinatífidas; segmentos oblongos, ápice emarginado (raro arredondado); venação furcada acompanhando a dissecção laminar. Soros apicais nos segmentos; indúsio obovado, imerso no tecido laminar até pela metade.

Material examinado: Belém, Área de Pesquisa Ecológica do Rio Guamá, Reserva do Mocambo, 18.IV.2005, M.R. Pietrobom 5896 (MG); idem, Colônia Augusto Montenegro, Igarapé Pitoró, 18.IX.1958, R.L. Fróes 34653 (IAN).

Material adicional: BRASIL. PERNAMBUCO: Jaqueira, Corrégo de guariba, 06.XII.2001, M.S. Lopes \& M.R. Pietrobom 517 (RB).

Hymenophyllum abruptum distingue-se das demais espécies do gênero que ocorrem na MMB pela lâmina geralmente ternada, diminuta e pelo indúsio obovado. Segundo Zotz \& Bueche (2000) essa espécie ocorre no dossel da floresta (com registro a 25 metros acima do solo) o que explica a escassez de material herborizado e a dificuldade de registrá-la em campo.

Espécie neotropical com registros no México, Guatemala, Honduras, Costa Rica, Panamá, Grandes Antilhas e Guiana Francesa. No Brasil ocorre no domínio fitogeográfico Amazônia (AM, $\mathrm{PA}, \mathrm{AC}$ e PE). Na MMB foi registrada sobre troncos de árvores em mata de terra firme e igapó.

2. Hymenophyllum hirsutum (L.) Sw., J. Bot. (Schrader) 1800(2): 99. 1801.

Fig. $2 h-j$

Frondes 2-7 cm compr. × 0,8-2 cm larg., espaçadas, monomorfas; pecíolo $0,5-2 \mathrm{~cm}$ compr., alado (pelo menos no ápice), tricomas castanho-claros, bifurcados ou estrelados no eixo e na ala; lâmina pinado-pinatífida, ovada a oblongo-lanceolada, margem levemente crispada com tricomas de forma variável, bifurcados com um ramo simples e outro furcado ou ambos os ramos furcados, biestrelados pedicelados ou sésseis, superfície laminar glabra; raque alada com tricomas semelhantes aos do pecíolo; pinas 4-8(-9) pares, pinatífidas; segmentos lineares, ápice emarginado; venação furcada acompanhando a dissecção laminar com tricomas semelhantes aos da margem da lâmina. Soros apicais nos segmentos; indúsio subcircular a ovado, parcialmente imerso no tecido laminar.

Material examinado: Belém, Ilha do Mosqueiro, 13.IV. 2005, J.M. Costa et al. 120 (MG); Benevides, Pa-17, 08.X.1974, H.P. Bautista 138 (MG); Santa Barbara do Pará, Estação Ecológica do Gunma, 01.VI. 2009, M.R. Pietrobom 8266 (MG).

Material adicional: GUIANA: Potaro-Siparuni region, 22.V.1991, T. DcDowell et al. 4879 (HB).

Hymenophyllum hirsutum (L.) Sw. apresenta tricomas estrelados, o que a diferencia das demais espécies do gênero que ocorrem na MMB. Assemelha-se com Hymenophyllum kaieteurum Jenman, de ocorrência nas Guianas, pela presença de tricomas marginais furcados. Porém $H$. kaieteurum possui os tricomas furcados basalmente com ambos os ramos simples, enquanto que $H$. hirsutum pode apresentar um dos ramos ou ambos furcados mais de uma vez e ainda apresentar tricomas estrelados (Lellinger 1991).

Espécie neotropical com registros no México, Antilhas, Guiana, Guiana Francesa, Suriname, Venezuela, Colômbia, Equador, Peru e Bolívia. No Brasil ocorre nos domínios Amazônia e Floresta Atlântica (RR, AP, AM, PA, AC, RO, CE, PE, BA, MG, RJ, SP, PR, SC e RS). Na MMB foi registrada sobre troncos vivos ou em decomposição em matas de terra firme e igapó.

3. Hymenophyllum polyanthos (Sw.) Sw., J. Bot. (Schrad.) 1800 (2):101. $1801 . \quad$ Fig. 3a-c

Frondes 6,7-17 cm compr., 1,5-5 cm larg., espaçadas, monomorfas; pecíolo 1-4 cm compr., alado, ala às vezes reduzindo em direção à base, vestigial ou ausente, com tricomas castanhoescuros, simples na inserção com o caule; lâmina 

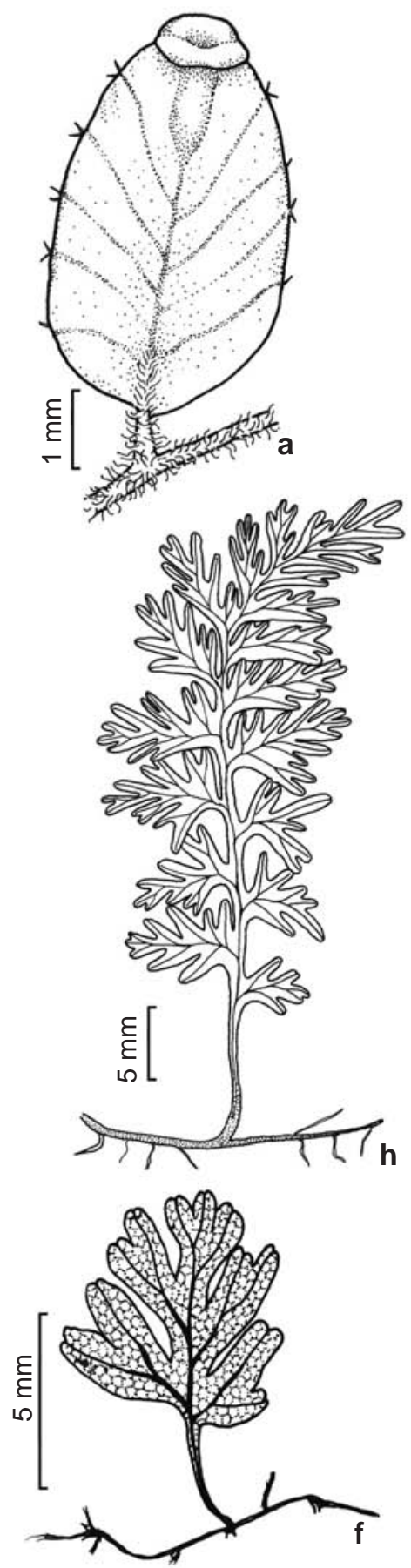
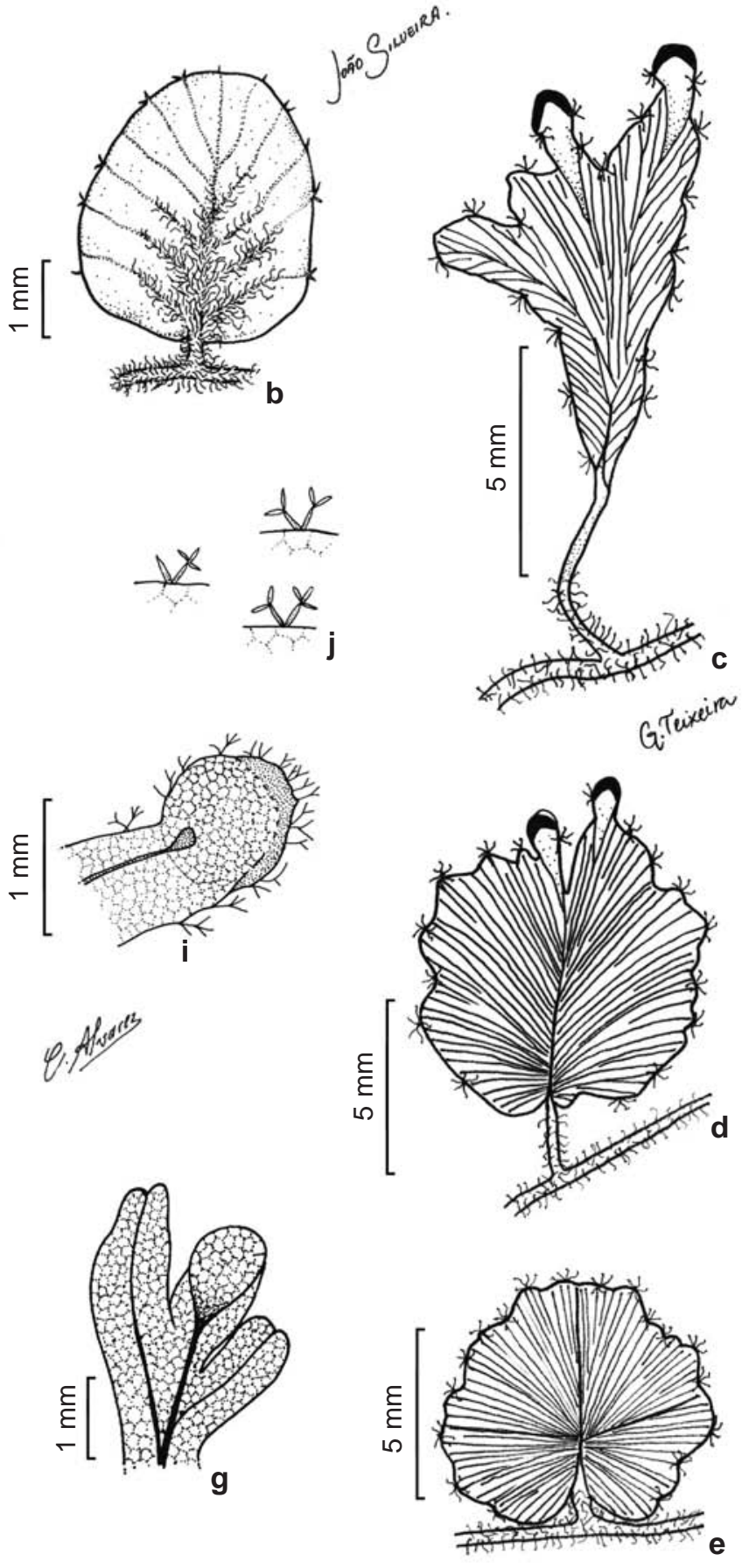

Figura 2 -a-b. Didymoglossum pinnatinervium (G. Teixeira 185) - a. fronde fértil; b. fronde estéril com detalhe dos tricomas na base da lâmina. c-e. Didymoglossum punctatum (G. Teixeira \& M.R. Pietrobom 11) - c,d. fronde fértil evidenciando as varias fileiras de células marginais escurecidas; e. fronde estéril. f-g. Hymenophyllum abruptum (M.R. Pietrobom 5896) - f. hábito; g. detalhe da lâmina e indúsio obovado. h-j. Hymenophyllum hirsutum (M.R. Pietrobom $8266)$ - h. hábito; i. detalhe da forma do indúsio; j. tricomas furcados, bifurcados e biestrelados.

Figure 2 - a-b. Didymoglossum pinnatinervium (G. Teixeira 185) - a. fertile frond; b. sterile frond with detail of the hairs in lower surface. c-e. Didymoglossum punctatum (G. Teixeira \& M.R. Pietrobom 11) - c,d. fertile frond and the broad border of dark cells; e. sterile frond. f-g. Hymenophyllum abruptum (M.R. Pietrobom 5896) - f. habit; g. blade detail and obovate indusium. h-j. Hymenophyllum hirsutum (M.R. Pietrobom 8266) - h. habit; i. detail of the indusium form; j. forked, twice-forked and bistellate hairs. 
2-3-pinatífida, oblongo-lanceolada, deltóide, ovada a elíptica, margem inteira, glabra, superfície laminar glabra; raque alada, glabra; pinas 4-15 pares, 1-2-pinatífidas; segmentos linear-oblongos, ápice emarginado; venação furcada acompanhando a dissecção laminar. Soros apicais nos segmentos; indúsio orbicular a oval, pelo menos a base imersa no tecido laminar.

Material selecionado: Belém, Ilha de Mosqueiro, mata do Pirajuçara, 29.IX.2005, J.M. Costa \& M.R. Pietrobom 329 (MG); Benevides, Balneário Paricatuba, 08.X.1974, H.P. Bautista 131 (MG); Castanhal, Ariboquinha, 5.VIII.1899, M. Guedes 1652 (MG); Santa Barbara do Pará, Parque Ecológico do Gunma, 12.V.2006, M.R. Pietrobom et al. 6265 (MG); Santa Izabel do Pará, Balneário Porto de Minas, 07.II.2012, G. Teixeira \& M.R. Pietrobom 174 (MG).

Hymenophyllum polyanthos é uma espécie que possui uma grande quantidade de sinônimos e variedades já descritos (Windisch 1996), principalmente por apresentar grande variação morfológica no tamanho e forma da fronde, presença ou não de ala no pecíolo e até mesmo a forma do indúsio (Mickel \& Smith 2004). De acordo com Hennequin et al. (2006), H. polyanthos é um complexo de espécies que necessita de uma revisão taxonômica.

Espécie pantropical com registros no México, Honduras, Nicarágua, Panamá, Guiana, Guiana Francesa, Suriname, Venezuela, Colômbia, Equador, Peru, Bolívia; África e Ásia. No Brasil ocorre nos domínios Amazônia, Cerrado e Floresta Atlântica (RR, AP, AM, PA, AC, RO, TO, MT, MS, GO, DF, MA, CE, PE, BA, MG, ES, RJ, SP, PR, SC e RS). Na MMB foi registrada em matas de terra firme, igapó e várzea sobre troncos vivos ou em decomposição.

Polyphlebium Copel., Philipp. J. Sci. 67: 55. 1938. Plantas epífitas. Caule longo-reptante, filiforme, com tricomas e raízes delgadas. Frondes espaçadas, monomorfas; pecíolo alado ou não, glabro ou piloso; lâmina 1 a 4-pinatífida, oval a oblonga, margem inteira, glabra, superfície laminar glabra ou com tricomas esparsos na face abaxial; segmentos linear-oblongos, ápice emarginado; venação furcada acompanhando a dissecção laminar, sem falsas vênulas, falsa vênula submarginal e vênula marginal coletora. Soros apicais nos segmentos; indúsio tubular, campanulado, livre ou imerso no tecido laminar, bilabiado ou não, lábios sem fileiras de células marginais escurecidas; receptáculo longamente exserto.
Gênero com ocorrência comum em regiões temperadas do hemisfério sul e florestas montanhosas de baixa altitude, com aproximadamente 15 espécies (Ebihara et al. 2006). No Brasil ocorrem quatro espécies (Windisch 2014) e no estado do Pará, somente Polyphlebium diaphanum foi registrada até o momento (Costa \& Pietrobom 2010).

A lâmina extremamente fina, a venação furcada com vênulas seguindo a divisão laminar e bem espessas assemelha este gênero com Hymenophyllum, porém a forma do indúsio tubular com receptáculo exserto o aproxima de Trichomanes. Foi descrito primeiramente por Copeland (1938), no entanto, durante muitos anos as espécies foram incluídas na secção Phlebiophyllum dentro de Trichomanes (Morton 1968). A revisão de Ebihara et al. (2006) rearranjou essas espécies dentro do gênero proposto por Copeland (1938).

1. Polyphlebium diaphanum (Kunth) Ebihara \& Dubuisson, Blumea 51(2): 240. $2006 . \quad$ Fig. 3d-e Frondes 3,5-7 cm compr. $\times 1,5-2,5 \mathrm{~cm}$ larg., espaçadas, monomorfas; pecíolo 0,5-1,5 cm compr., alado até a base, glabro; lâmina 2-3-pinatífida, ovada a oblonga, margem inteira, glabra, superfície laminar glabra; raque alada, glabra; pinas 5-7(-10) pares, 1-2-pinatífidas; segmentos linear-oblongos, ápice emarginado; venação furcada acompanhando a dissecção laminar, com tricomas diminutos na face abaxial da lâmina. Soros apicais nos segmentos; indúsio totalmente imerso no tecido laminar, ápice expandido, não bilabiado.

Material examinado: Santa Barbara do Pará, Parque Ecológico do Gunma, 12.V.2006, M.R. Pietrobom et al. 6268 (MG); idem, 09.VII.2008, M.R. Pietrobom et al. 7718 (MG); Santa Izabel do Pará, Balneário Porto de Minas, 07.II.2012, G. Teixeira \& M.R. Pietrobom 176 (MG).

Polyphlebium diaphanum foi registrada pela primeira vez na Amazônia brasileira por Costa \& Pietrobom (2010), sendo mais comumente encontrada nas regiões sul e sudeste do país. É facilmente confundida com $P$. hymenophylloides (Bosch) Ebihara \& Dubuisson que também ocorre com frequência nas regiões sul e sudeste do Brasil, porém $P$. hymenophylloides difere principalmente pelo pecíolo não alado ou alado apenas na porção distal, enquanto que $P$. diaphanum apresenta pecíolo alado até a base (Smith 1995). 
Espécie neotropical com registros no México, Guatemala, Panamá, Cuba, Guiana, Guiana Francesa, Venezuela, Colômbia, Equador, Peru e Bolívia. No Brasil ocorre nos domínios Amazônia e Floresta Atlântica (PA, BA, MG, ES, RJ, SP, PE e SC). Na MMB foi registrada sobre troncos vivos em matas de terra firme e várzea.

Trichomanes L., Sp. Pl. 2: 1097-1099. 1753.

Plantas epífitas, hemiepífitas ou terrestres. Caule curto a longo-reptante, decumbente ou ascendente, subereto a ereto, com tricomas e raízes rígidas. Frondes espaçadas, aproximadas ou fasciculadas, adpressas ou não ao substrato, monomorfas, subdimorfas ou acentuadamente dimorfas; pecíolo alado ou não, glabro ou piloso; lâmina simples, 1-2-pinatífida, pinatissecta a 1-pinada, de formato variável, margem ondulada, crenada, lobada ou denteada, glabra ou pilosa, superfície laminar glabra; segmentos ou pinas lineares a oblongos, ápice arredondado; venação pinada, às vezes com falsas vênulas perpendiculares as verdadeiras, ou ainda com uma vênula marginal coletora, sem falsa vênula submarginal. Soros apicais nos segmentos ou nas terminações das vênulas laterais; indúsio tubular, campanulado, livre ou imerso no tecido laminar, não bilabiado, sem fileiras de células marginais escurecidas; receptáculo exserto.

Gênero predominantemente neotropical com quatro subgêneros e aproximadamente 60 espécies (Ebihara et al. 2006). No Brasil ocorrem 33 espécies e no estado do Pará se tem registro de 18 espécies (Windisch 2014). Na área de estudo foram registradas nove espécies.

Trichomanes difere dos outros gêneros aqui estudados pela lâmina mais espessa (em geral) e com caule robusto portando raízes abundantes e rígidas, além de apresentar uma maior variedade de formas de vida (hemiepífitas e terrestres, além de epífitas) e frondes usualmente de grande porte.

\section{Chave de identificação para as espécies de Trichomanes da MMB}

1. Plantas hemiepífitas, adpressas ao substrato.

2. Lâmina 1-pinatífida; segmentos oblongos; margem crenado-lobada.

..2. Trichomanes ankersii

2'. Lâmina 2-pinatífida; segmentos lineares; margem levemente ondulada

6. Trichomanes pedicellatum

1’. Plantas terrestres ou epífitas, não adpressas ao substrato.

3. Frondes monomorfas; pecíolo piloso.

4. Pecíolo amplamente alado até próximo à base; tricomas do pecíolo castanho-escuros; margem lobada a mais incisa, glabra 3. Trichomanes arbuscula

4'. Pecíolo não alado, ou se alado, aleta muito estreita; tricomas do pecíolo castanho-claros a paleáceos; margem levemente crenada, pilosa.

5. Pecíolo estreitamente alado; pares de segmentos basais reflexos

1. Trichomanes accedens

5'. Pecíolo não alado; pares de segmentos basais perpendiculares a raque (raro reflexos)..

4. Trichomanes crispum

3'. Frondes subdimorfas ou dimorfas; pecíolo glabrescente.

6. Frondes dimorfas; lamina das frondes férteis simples.

7. Fronde estéril pectinada; falsas vênulas ausentes no tecido laminar; indúsio imerso no tecido laminar..... 8. Trichomanes trollii

7’. Fronde estéril pinada; falsas vênulas abundantes no tecido laminar; indúsio livre, séssil a curto-pedicelado 9. Trichomanes vittaria

6'. Frondes subdimorfas; lamina das frondes férteis pinadas.

8. Tecido laminar com falsas vênulas abundantes

7. Trichomanes pinnatum

8’. Tecido laminar sem falsas vênulas ou, se presentes, são escassas

5. Trichomanes hostmannianum 
1. Trichomanes accedens C. Presl, Abh. Königl. Böhm. Ges. Wiss., ser. 56: 374. 1851. Fig. 3f-h Plantas terrestres ou epífitas. Caule ascendente a subereto, curto a longo. Frondes 9-26 cm compr. $\times 2,5-5,5 \mathrm{~cm}$ larg., aproximadas, levemente arqueadas, não adpressas ao substrato, monomorfas; pecíolo 1-7 cm compr., estreitamente alado, piloso, com tricomas adensados, castanhoclaros a paleáceos; lâmina pinatissecta, linearlanceolada a linear-oblonga, com tricomas semelhantes aos do pecíolo na raque e vênulas em ambas as faces, margem levemente crenada, pilosa; raque alada, com ala muito estreita na base, alargando-se para o ápice; segmentos linear-oblongos, os pares basais reflexos; venação pinada, vênulas 1-furcadas, falsas vênulas e vênula marginal coletora ausentes. Soros 1-4 no ápice dos segmentos; indúsio imerso no tecido laminar, ápice levemente expandido, piloso.

Material examinado: Belém, 20.VIII.1902, $R$. Siqueira s.n. (MG); Santa Barbara do Pará, 02.XI.2011, G. Teixeira \& M.R. Pietrobom 148 (MG); idem, Parque Ecológico do Gunma, 15.V.2006, M.R. Pietrobom et al. 6263 (MG); Santa Izabel do Pará, VI.1908, s.c. (MG 9428).

Trichomanes accedens é muito semelhante a $T$. crispum, sendo que esta difere principalmente pelo pecíolo não alado e por possuir os pares de pinas basais geralmente perpendiculares a margem, enquanto $T$. accedens possui o pecíolo estreitamente alado e os pares de pinas basais reflexos (Windisch 1988). A característica mais marcante e que diferencia essas espécies é a presença ou não de ala no pecíolo, porém em $T$. accedens essa ala é muito estreita e muitas vezes se encontra muito danificada, o que dificulta a determinação da espécie.

Espécie com distribuição neotropical com ocorrência em Trinidad, Tobago, Guiana, Guiana Francesa, Suriname, Venezuela, Colômbia e Peru. No Brasil ocorre nos domínios Amazônia e Floresta Atlântica (AP, AM, PA, MT e BA). Na MMB foi registrada sobre troncos em decomposição em matas de terra firme e igapó.

2. Trichomanes ankersii C. Parker ex Hook. \& Grev., Icon. Filic. 2(11): 201. $1831 . \quad$ Fig. 4a-b Plantas hemiepífitas. Caule ascendente, curto a longo, emitindo ramo aéreo escandente com tricomas rizoidais na face abaxial. Frondes $3-7 \mathrm{~cm}$ compr., 1,4-3,5 cm larg., espaçadas, alternadas no ramo, adpressas ao substrato, monomorfas; pecíolo 0,1-0,2 cm compr., não alado, com densos tricomas de aderência na face abaxial; lâmina 1-pinatífida, deltóide a oblonga, esparsos tricomas de aderência sobre a raque e vênulas na face abaxial, margem crenado-lobada, glabra; raque alada; segmentos oblongos, comumente com um lobo basioscópico bem desenvolvido no par de segmentos proximais; venação pinada, vênulas livres, falsas vênulas e vênula marginal coletora ausentes. Soros 1-4 nas terminações das vênulas laterais, usualmente no lado acroscópico do segmento; indúsio livre, pedicelado, ápice levemente expandido, glabro.

Material selecionado: Barcarena, Ilha de Trambioca, 23.IX.2009, G. Teixeira et al. 121 (MG); Belém, Ilha de Mosqueiro, 13.IV.2005, J.M. Costa et al. 117 (MG); Castanhal, estrada para o rio Apeú, 20.VIII.2012, G. Teixeira \& M.R. Pietrobom 210 (MG); Santa Barbara do Pará, Balneário Baiacu, 02.XI.2011, G. Teixeira \& M.R. Pietrobom 154 (MG).

Trichomanes ankersii e T. pedicellatum Desv. representam as hemiepífitas do gênero na MMB. É muito semelhante a T. tuerckheimii H. Christ, que também ocorre no Pará, porém a margem dos segmentos (em geral) é inteira nessa última espécie, enquanto que em $T$. ankersii a margem é crenada (Smith 1995).

Espécie neotropical com ocorrência no Panamá, Trinidad, Guiana, Guiana Francesa, Suriname, Venezuela, Colômbia, Equador, Peru e Bolívia. No Brasil é restrita ao domínio fitogeográfico Amazônia (RR, AM, PA, AC, RO e MT). Na MMB foi registrada comumente sobre troncos de arvoretas em matas de terra firme e várzea.

3. Trichomanes arbuscula Desv., Mém. Soc. Linn. Paris 6: 326. $1827 . \quad$ Fig. 4c-d

Plantas terrestres ou epífitas. Caule curtoreptante a ascendente. Frondes 6-11 cm compr., 2,5-4 cm larg., fasciculadas, não adpressas ao substrato, monomorfas; pecíolo 1,5-4 cm compr., amplamente alado até próximo à base, piloso, com tricomas adensados, castanho-escuros; lâmina pinatífida, ovada a deltóide, com tricomas semelhantes aos do pecíolo esparsos na raque e vênulas principais dos segmentos (face abaxial), margem lobada a mais incisa, glabra; raque uniformemente alada; segmentos oblongos; venação pinada, vênulas livres, falsas vênulas e vênula marginal coletora ausentes. Soros 2-6 no ápice dos segmentos; indúsio imerso no tecido laminar, ápice expandido, glabro.

Material examinado: Belém, Ilha de Mosqueiro, 13.IV.2005, J.M. Costa et al. 125 (MG); Benevides, PA- 
17 ramal pra zona açucareira, 8.X.1974, H.P. Bautista 139 (MG); Santa Barbara do Pará, 02.XI.2011, G. Teixeira \& M.R. Pietrobom 146 (MG).

Trichomanes arbuscula assemelha-se a Trichomanes macilentum Bosch pela lâmina pinatífida com segmentos lobados ou mais incisos, porém diferem na forma do ápice do indúsio, que em T. macilentum é truncado (Smith 1995) e em $T$. arbuscula é expandido. Indivíduos jovens porém férteis são de difícil determinação devido ao formato diferenciado da lâmina e tamanho diminuto da fronde, somente o detalhe da forma do caule e da raque e pecíolo uniformemente alados permitem a determinação da espécie.

Espécie neotropical com ocorrência na Jamaica, Trinidad, Guiana, Guiana Francesa, Suriname, Venezuela, Colômbia e Peru. No Brasil ocorre nos domínios Amazônia e Floresta Atlântica (AP, AM, PA, AC, MT, PE, BA, ES e SP). Na MMB foi registrada, em geral, sobre troncos em decomposição em matas de terra firme e várzea.

\section{Trichomanes crispum L., Sp. Pl. 2: 1097.} 1753.

Fig. 4e-g

Plantas epífitas. Caule curto-reptante a subereto. Frondes 7,5-19 cm compr., 2,5-3 cm larg., aproximadas, levemente arqueadas, não adpressas ao substrato, monomorfas; pecíolo 1,5-2,5 cm compr., não alado, piloso, com tricomas adensados, paleáceos; lâmina pinada proximalmente a pinatífida distalmente, linearlanceolada a linear-oblonga, tricomas semelhantes aos do pecíolo na raque e vênulas em ambas as faces, margem levemente crenada, pilosa; raque alada em toda a sua extensão ou somente na parte distal; segmentos linear-oblongos, os pares basais perpendiculares à raque (raro reflexos); venação pinada, vênulas 1-furcadas, falsas vênulas e vênula marginal coletora ausentes. Soros 1-4 no ápice dos segmentos, indúsio imerso no tecido laminar, ápice levemente expandido, piloso.

Material examinado: Santa Barbara do Pará, Parque Ecológico do Gunma, 09.VII.2008, M.R. Pietrobom et al. 7723 (MG).

Material adicional: BRASIL. AMAPÁ: nordeste do Rio Ingarari, 16.IX.1960, H.S. Irwin et al. 48312 (MG); BRASIL. PARÁ: Breves, Vila Nova Aramá, 24.IX.1968, P. Cavalcante 2042 (MG).

Trichomanes crispum e T. accedens são espécies muito semelhantes morfologicamente (ver comentário T. accedens). Na Amazônia brasileira essas espécies juntamente com T. egleri P. G. Windisch, T. humboldtii (Bosch) Lellinger, T. martiusii C. Presl e T. vandenboschii P. G. Windisch formam um complexo denominado T. crispum, cuja diferenciação é bastante problemática devido ao pequeno número de caracteres úteis para diferenciálas (Windisch 1988).

Espécie neotropical com ocorrência no México, América Central, Antilhas, Trinidad, Guiana, Guiana Francesa, Suriname, Venezuela, Colômbia, Equador, Peru, Bolívia, Paraguai e Uruguai. No Brasil ocorre nos domínios fitogeográficos Amazônia e Cerrado (RR, AP, AM, PA, AC, RO, MA e CE). Na MMB foi registrada sobre tronco em decomposição em mata de terra firme.

\section{Trichomanes hostmannianum (Klotzsch)} Kunze, Bot. Zeitung (Berlin) 5: 352. 1847.

Fig. 4h-i

Plantas terrestres. Caule curto-reptante a ereto. Frondes (12-)18-33 cm compr. × (3,5-)5-10 cm larg., fasciculadas, não adpressas ao substrato, subdimorfas, as férteis mais longas e eretas; pecíolo 7-18 cm compr., não alado ou estreitamente alado na porção distal, glabrescente, tricomas esparsos, castanho-escuros, septados; lâmina pinada, deltóide a ovada, com esparsos tricomas semelhantes aos do pecíolo sobre a raque e vênulas principais na face abaxial, margem denteada, glabra; raque alada somente na porção distal, às vezes terminando em ápice flageliforme; pinas 8-12 pares, lineares a oblongas; venação pinada, vênulas 1-2 furcadas, unidas no ápice por uma nervura marginal coletora, falsas vênulas escassas ou ausentes. Soros numerosos em ambas as margens; indúsio livre, séssil a curto-pedicelado, ápice truncado a bilobado ou levemente expandido, glabro.

Material selecionado: Barcarena, Rio Tauá, 11.XI.1984, A. Lins et al. 440 (MG); Belém, Ilha de Mosqueiro, 11.VII.2005, J.M. Costa et al. 229 (MG); Castanhal, estrada para o rio Apeú, 20.VIII.2012, G. Teixeira \& M.R. Pietrobom 214 (MG); Santa Barbara do Pará, Parque Ecológico do Gunma, M.R. Pietrobom \& P. Sanjuan 6061 (MG).

Trichomanes hostmannianum se assemelha a T. pinnatum no formato e divisão da lâmina, porém distingue-se por não apresentar falsas vênulas conectando as verdadeiras ou, se presentes, essas vênulas são escassas, enquanto $T$. pinnatum apresenta falsas vênulas abundantes conectando as verdadeiras. T. hostmannianum ocorre geralmente em áreas alagadas como várzea e igapó, enquanto T. pinnatum ocorre preferencialmente em matas de terra firme. 


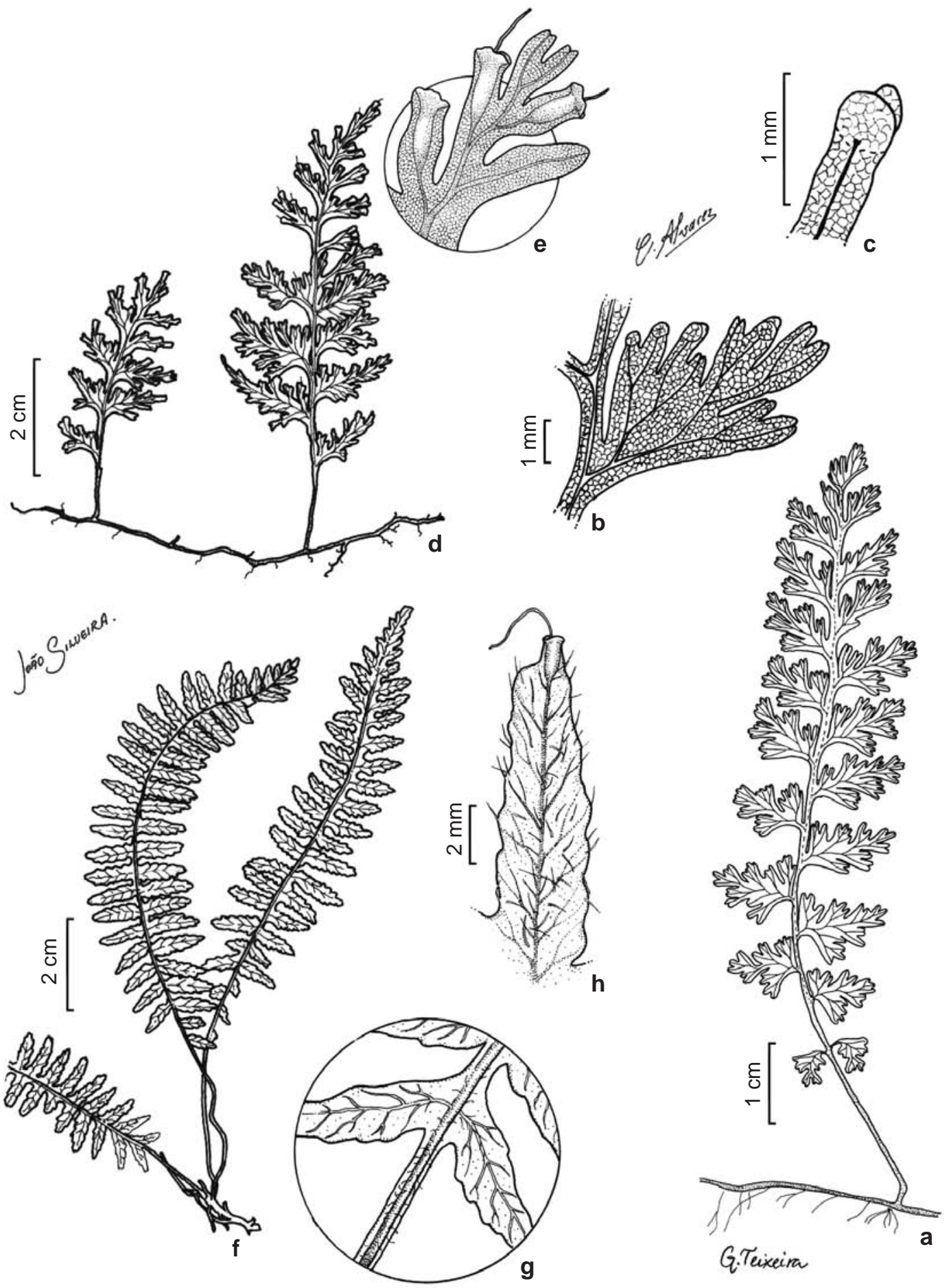

Figura 3 - a-c. Hymenophyllum polyanthos (G. Teixeira \& M.R. Pietrobom 169) - a. hábito; b. detalhe da lâmina; c. detalhe da forma do indúsio. d-e. Polyphlebium diaphanum (M.R. Pietrobom et al. 6268) - d. hábito; e. detalhe da lâmina e do indúsio. f-h. Trichomanes accedens (G. Teixeira \& M.R. Pietrobom 148) - f. hábito; g. detalhe da ala estreita no pecíolo; h. detalhe da lâmina e indúsio.

Figure 3 - a-c. Hymenophyllum polyanthos (G. Teixeira \& M.R. Pietrobom 169) - a. habit; b. blade detail; c. detail of the indusium form. d-e. Polyphlebium diaphanum (M.R. Pietrobom et al. 6268) - d. habit; e. blade and indusium detail. f-h. Trichomanes accedens (G. Teixeira \& M.R. Pietrobom 148) - f. habit; g. detail of the alate stipe; h. blade and indusium detail. 


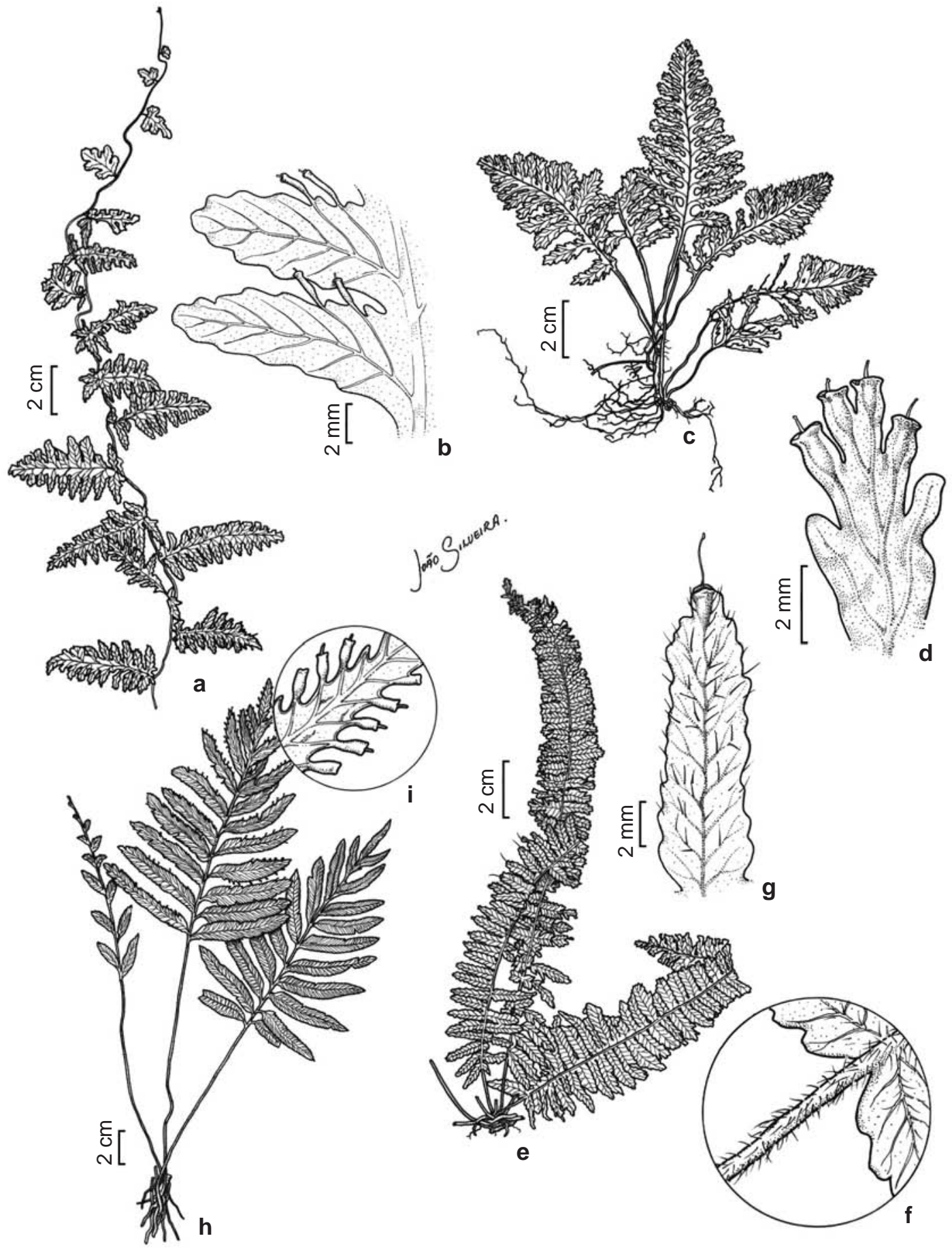

Figura 4 -a-b. Trichomanes ankersii (G. Teixeira \& M.R. Pietrobom 154) - a. hábito; b. detalhe da lâmina e indúsio. c-d. Trichomanes arbuscula (G. Teixeira \& M.R. Pietrobom 146) - c. hábito; d. detalhe da lâmina e indúsio. e-g. Trichomanes crispum (M.R. Pietrobom et al. 7723) - e. hábito; f. detalhe do pecíolo não alado; g. detalhe da lâmina e indúsio. h-i. Trichomanes hostmannianum (et al. 229) - h. hábito; i. detalhe da lâmina fértil e falsas vênulas escassas. Figure 4 - a-b. Trichomanes ankersii (G. Teixeira \& M.R. Pietrobom 154) - a. habit; b. blade and indusium detail. c-d. Trichomanes arbuscula (G. Teixeira \& M.R. Pietrobom 146) - c. habit; d. blade and indusium detail. e-g. Trichomanes crispum (M.R. Pietrobom et al. 7723) - e. habit; f. detail of the exalate stipe; g. blade and indusium detail. h-i. Trichomanes hostmannianum (J.M. Costa et al. 229) - h. habit; i. detail of the fertile blade and scarce false veinlets. 
Espécie neotropical com ocorrência na Guiana, Guiana Francesa, Suriname, Venezuela, Colômbia, Equador, Peru e Bolívia. No Brasil ocorre nos domínios Amazônia e Cerrado (RR, AM, PA, AC, RO, TO, MT, MS, DF, MA e BA). Na MMB foi registrada principalmente em áreas alagadas ou sujeitas a inundações ou próximo a cursos de água em matas de igapó ou várzea, raro em matas de terra firme.

6. Trichomanes pedicellatum Desv., Ges. Naturf. Freunde Berlin Mag. 5: 328.1811. Fig. 5a-b

Plantas hemiepífitas. Caule ascendente, curto, emitindo ramo aéreo escandente com tricomas rizoidais na face abaxial. Frondes 5-22(-30) cm compr. $\times 1,5-4,5 \mathrm{~cm}$ larg., espaçadas, alternadas no ramo, adpressas ao substrato, monomorfas; pecíolo 1-2 cm compr., não alado, com densos tricomas de aderência na face abaxial; lâmina 2-pinatífida, lanceolada a oblonga, com esparsos tricomas de aderência sobre a raque e vênulas na face abaxial, margem inteira, levemente ondulada, glabra; raque uniformemente alada; segmentos lineares; venação pinada, apenas uma vênula nos segmentos terminais, falsas vênulas e vênula marginal coletora ausentes. Soros 1-4 nas terminações das vênulas, usualmente no lado acroscópico; indúsio livre, longo pedicelado, ápice levemente expandido, glabro.

Material selecionado: Barcarena, Ilha de Trambioca, 23.IX.2009, G. Teixeira et al. 122 (MG); Belém, Parque Ambiental de Belém, 16.VIII.2003, J.M. Costa \& J.L. Nunes 39 (MG); Benevides, PA-17 na estrada do Mosqueiro, 8.X.1974, H.P. Bautista 134 (MG); Bujaru, Vila Ponta de Terra, 14.VIII.2012, G. Teixeira \& M.R. Pietrobom 196 (MG); Castanhal, estrada para o rio Apeú, 20.VIII.2012, G. Teixeira \& M.R. Pietrobom 211 (MG); Inhangapi, Vila Pernambuco, 09.II.2012, G. Teixeira \& M.R. Pietrobom 182 (MG); Santo Antônio do Tauá, RPPN Klagesi, 09.IX.2006, G. Teixeira \& M.R. Pietrobom 182 (MG); Santa Barbara do Pará, Parque Ecológico do Gunma, 12.V.2006, M.R. Pietrobom et al. 6271 (MG); Santa Izabel do Pará, Balneário Porto de Minas, 07.II.2012, G. Teixeira \& M.R. Pietrobom 171 (MG).

Dentre as espécies registradas na MMB, Trichomanes pedicellatum se assemelha com $T$. ankersii pela forma de vida, mas difere pela lâmina 2-pinatífida e pelos segmentos terminais lineares com uma nervura apenas, enquanto em $T$. ankersii a lâmina é pinatífida e os segmentos oblongos com venação pinada. Lellinger (1991) comentou sobre a grande variação morfológica da lâmina dessa espécie nos diferentes estágios da planta, o que muitas vezes torna difícil sua determinação.
Espécie neotropical com registros em Trinidad, Guiana, Guiana Francesa, Suriname e Bolívia. No Brasil ocorre nos domínios Amazônia e Floresta Atlântica (AP, AM, PA, MT, PE e BA). Na MMB foi registrada comumente sobre troncos vivos em matas de terra firme e várzea.

7. Trichomanes pinnatum Hedw., Fil. Gen. Sp., t. 4, f. 1. 1799.

Fig. 5c-d

Plantas terrestres. Caule curto-reptante a ereto. Frondes (5-)9-49(-62) cm compr. × (2-)4-18(-24) cm larg., fasciculadas, não adpressas ao substrato, subdimorfas, frondes férteis mais longas e eretas; pecíolo (1,5-)3,5-29 cm compr., não alado ou estreitamente alado na porção distal, glabrescente com esparsos tricomas castanho-escuros, septados; lâmina pinada, deltóide a ovada, com esparsos tricomas semelhantes aos do pecíolo sobre a raque e vênulas principais na face abaxial, margem denteada, glabra; raque alada somente na porção distal, às vezes terminando em ápice flageliforme; pinas 4-11 pares, lineares a oblongas; venação pinada, vênulas 1-2 furcadas, unidas no ápice por uma nervura marginal coletora, falsas vênulas abundantes e perpendiculares às verdadeiras. Soros numerosos em ambas as margens; indúsio tubular, livre, séssil a curto-pedicelado, ápice truncado a bilobado, glabro. Material selecionado: Barcarena, Ilha de Trambioca, 23.IX.2009, G. Teixeira et al. 128 (MG); Belém, Parque Ambiental de Belém, 02.VI.2003, J.L. Nunes \& J.M. Costa 03 (MG); Bujaru, Vila Ponta de Terra, 14.VIII.2012, G. Teixeira \& M.R. Pietrobom 195 (MG); Castanhal, Estrada pro Rio Apeú, 20.VIII.2012, G. Teixeira \& M.R. Pietrobom 204 (MG); Marituba, Fazenda da Pirelli, 29.VII.1997, S.V. Costa Neto et al. 124 (MG); Santa Barbara do Pará, Reserva Ecológica do Gunma, 09.VII.2008, M.R. Pietrobom et al. 7725 (MG); Santo Antônio do Pará, RPPN Klagesi, 05.XII.2007, R.S. Tavares 43 (MG).

Trichomanes pinnatum se assemelha a $T$. vittaria no formato da lâmina estéril e pela presença de falsas vênulas perpendiculares às verdadeiras, sendo diferenciadas pelo formato da pina fértil, que em $T$. vittaria é simples e linear, enquanto em $T$. pinnatum é pinada e varia de deltóide a ovada. Outra espécie muito semelhante é $T$. hostmannianum (ver comentário dessa espécie).

Espécie neotropical com ocorrência no México, Porto Rico, Trinidad, Guiana, Guiana Francesa, Suriname, Venezuela, Colômbia, Equador, Peru e Bolívia. No Brasil ocorre nos domínios Amazônia, Floresta Atlântica e Cerrado (RR, AP, AM, PA, AC, RO, TO, MT, MS, GO, 


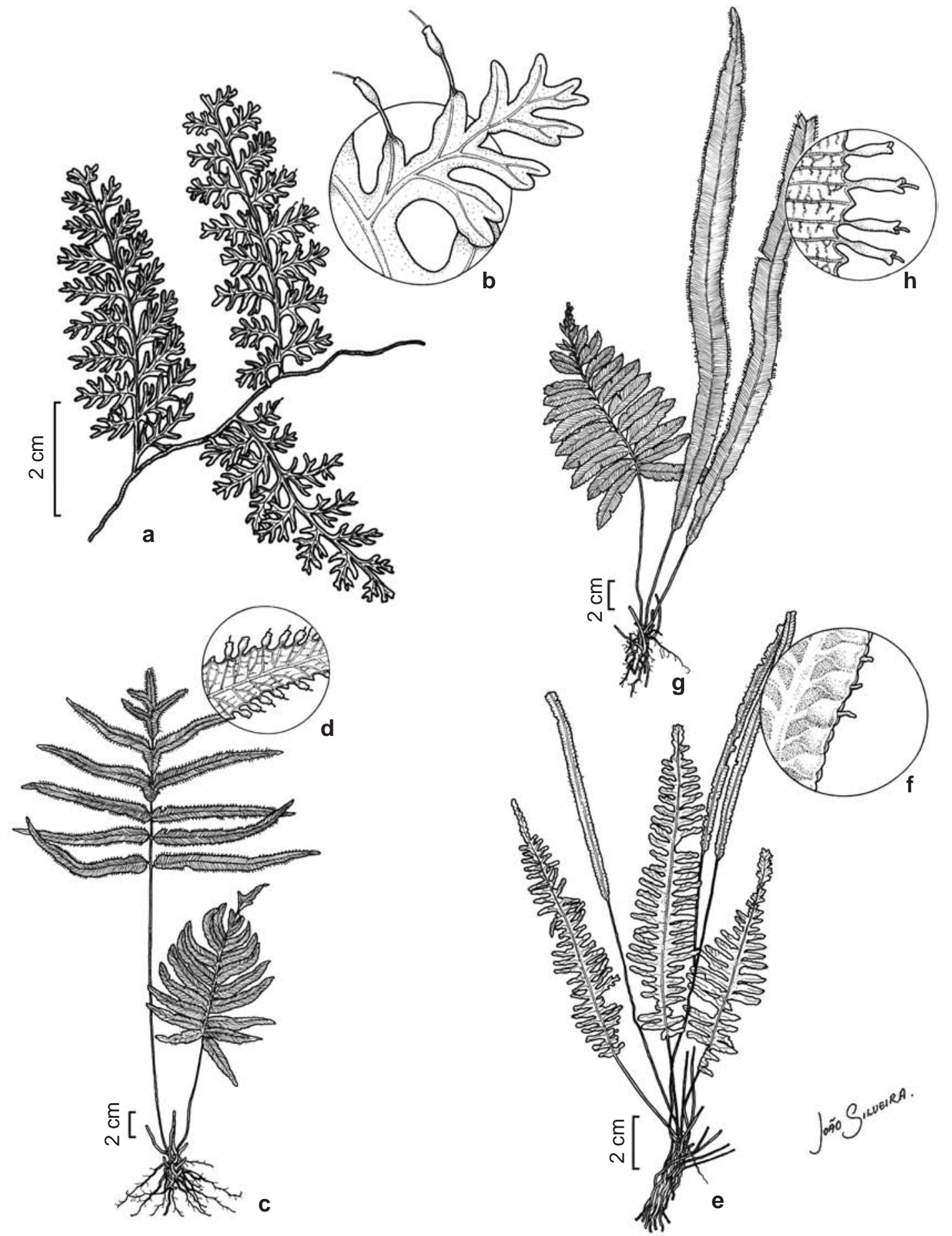

Figura 5 - a-b. Trichomanes pedicellatum (J.M. Costa \& J.L. Nunes 39) - a. hábito; b. detalhe da lâmina e indúsio. c-d. Trichomanes pinnatum (J.M. Costa \& J.L. Nunes 03) - c. hábito; d. detalhe da lâmina fértil e das falsas vênulas abundantes. e-f. Trichomanes trollii (M.R. Pietrobom et al. 6259) - e. hábito; f. detalhe da lâmina fértil. g-h. Trichomanes vittaria (G. Teixeira \& J.B. Silveira 187) - g. hábito; h. detalhe da lâmina fértil e falsas vênulas abundantes. Figure 5 - a-b. Trichomanes pedicellatum (J.M. Costa \& J.L. Nunes 39) - a. habit; b. blade and indusium detail. c-d. Trichomanes pinnatum (J.M. Costa \& J.L. Nunes 03) - c. habit; d. detail of the fertile blade and abundant false veinlets. e-f. Trichomanes trollii (M.R. Pietrobom et al. 6259) - e. habit; f. detail of the fertile blade. g-h. Trichomanes vittaria (G. Teixeira \& J.B. Silveira 187) - g. habit; h. detail of the fertile blade and abundant false veinlets. 
DF, MA, PI, CE, PB, PE, AL, BA, MG e ES). Na MMB foi registrada próximo a córregos de água, geralmente em floresta de terra firme, raro em igapó ou várzea.

8. Trichomanes trollii Bergdolt, Flora 127: 256, 264, f. 3. 1933.

Fig. 5e-f

Plantas terrestres. Caule decumbente ou ereto. Frondes aproximadas, não adpressas ao substrato, dimorfas; fronde estéril pectinada 9-18 cm compr. × 1-2,5 cm larg.; pecíolo 3-9 cm compr., não alado ou estreitamente alado, glabrescente com esparsos tricomas castanho-escuros, septados; lâmina lanceolada a oblonga, com esparsos tricomas semelhantes aos do pecíolo sobre a raque e vênulas principais na face abaxial, margem levemente ondulada, glabra; raque alada, às vezes terminando em ápice flageliforme; segmentos lineares; venação pinada, vênulas 1-furcadas, falsas vênulas e vênula marginal coletora ausentes. Fronde fértil inteira 18-22 cm compr., 0,3-0,5 cm larg.; pecíolo 8-10 cm compr., não alado ou estreitamente alado, glabrescente; lâmina linear, margem inteira a levemente ondulada, glabra. Soros numerosos dispostos ao longo da margem; indúsio imerso no tecido laminar, ápice truncado a levemente expandido, glabro.

Material examinado: Belém, Ilha de Mosqueiro, 27.X.2005, J.M. Costa \& M.R. Pietrobom 344 (MG); idem, 23.XI.2005, J.M. Costa \& M.R. Pietrobom 398 (MG); Santa Barbara do Pará, Parque Ecológico do Gunma, 09.VIII.2005, M.R. Pietrobom \& P. Sanjuan 6071 (MG); idem, 12.V.2006, M.R. Pietrobom et al. 6259 (MG).

T. diversifrons (Bory) Mett. é outra espécie que se caracteriza pelo forte dimorfismo foliar muito semelhante a $T$. trolli e também com ampla ocorrência na Amazônia brasileira, no entanto difere pela lâmina foliar fértil com margem denteada (Windisch 1996), que em T. trollii é inteira a levemente ondulada.

Espécie neotropical com ocorrência na Guiana, Guiana Francesa, Suriname, Venezuela, Colômbia, Equador, Peru e Bolívia. No Brasil é restrita ao domínio Amazônia (RR, AP, AM, PA, AC e MT). Na MMB foi registrada em barrancos próximos a cursos d'água em matas de terra firme.

9. Trichomanes vittaria DC. ex Poir., Enc. 8: 65. 1808.

Fig. 5g-h

Plantas terrestres. Caule curto-reptante a ascendente. Frondes fasciculadas ou aproximadas, não adpressas ao substrato, dimorfas; fronde estéril pinada 21,5-22,5 cm compr. × 7-12 cm larg.; pecíolo 5,5-11,5 cm compr., não alado ou estreitamente alado na porção distal, glabrescente com esparsos tricomas castanho-escuros, septados; lâmina deltóide a ovada, com esparsos tricomas semelhantes aos do pecíolo sobre a raque e vênulas principais na face abaxial, margem denteada, glabra; raque alada somente no ápice, às vezes terminando em ápice flageliforme; pinas ca. 12 pares, linear a oblonga; venação pinada, vênulas 1-2 furcadas, unidas no ápice por uma nervura marginal coletora, falsas vênulas abundantes perpendiculares às verdadeiras. Fronde fértil inteira 24-55(-64) cm compr., 1,5-3 cm larg.; pecíolo 6-10(-13) cm compr., não alado ou estreitamente alado na porção distal, glabrescente; lâmina linear, com tricomas esparsos semelhantes aos do pecíolo sobre a raque na face abaxial. Soros numerosos ao longo das margens; indúsio livre, séssil a curto pedicelado, ápice truncado a bilobado, glabro.

Material selecionado: Barcarena, Ilha de Trambioca, 23.IX.2009, G. Teixeira et al. 139 (MG); Belém, Reserva Catu, 11.XI.1992, S.T. Rodrigues \& O.C. Nascimento 92 (IAN); idem, Reserva Aurá, 18.II.1992, S.T. Rodrigues \& M.R. Santos 69 (IAN); idem, Reserva do Mocambo, 17.V.2012, G. Teixeira \& J.B. da Silveira 187 (MG).

Trichomanes vittaria é semelhante a $T$. hostmannianum e $T$. pinnatum, mas pode ser distinta pela lâmina fértil simples. Contudo indivíduos jovens e estéreis podem ser confundidos com $T$. pinnatum, pois ambas apresentam falsas vênulas conectando as vênulas verdadeiras (Windisch 1996).

Espécie neotropical com ocorrência na Guiana, Guiana Francesa, Suriname e Colômbia. No Brasil ocorre no domínio Amazônia (RR, AP, AM, PA, AC, RO, MT e MA). Na MMB foi registrada muitas vezes sobre barrancos em matas de terra firme, igapó e/ou várzea.

\section{Considerações Finais}

As espécies ocorrentes na área de estudo representam mais da metade das espécies de Hymenophyllaceae registradas para o Estado do Pará. Os municípios de Belém e Santa Barbara do Pará apresentaram maior riqueza específica provavelmente em decorrência dos parques ecológicos existentes que exibem um bom grau de conservação. Nessas áreas também foram encontradas espécies escassas nas coleções herborizadas, o que ressalta a importância desses parques para compreensão e manutenção da biodiversidade local. 


\section{Agradecimentos}

Ao CNPq, a concessão da bolsa de Mestrado ao primeiro autor; ao Museu Paraense Emilio Goeldi (Coordenação de Botânica), a infraestrutura disponibilizada. Ao projeto PNADB e a PROPED (Ufra), o auxílio financeiro para realização das coletas de campo e visita aos herbários. Aos curadores dos herbários BHCB, HB, IAN, INPA, MG, R, RB e SP, o acesso ao acervo e empréstimo de material. Ao Dr. Jefferson Prado, o auxílio na determinação de um espécime duvidoso de Trichomanes arbuscula. Aos ilustradores botânicos, Carlos Alvarez e João Barros da Silveira, a grande parte dos desenhos que ilustram esse estudo e ao M. Sc. Gildo Vieira Feitoza, o auxílio na confecção das pranchas.

\section{Referências}

Boer, J.G.W. 1962. The new world species of Trichomanes sect. Didymoglossum and Microgonium. Acta Botanica Neerlandica 11: 277-330.

Bridson, D. \& Forman, L. 1998. The Herbarium Handbook, 3 ed. The Royal Botanic Gardens, Kew. 333p.

Copeland, E.B. 1938. Genera Hymenophyllacearum. Philippine Journal of Science 51: 2-110.

Costa, J.M. \& Pietrobom, M.R. 2007. Pteridófitas (Lycophyta e Monilophyta) da Ilha de Mosqueiro, município de Belém, Estado do Pará, Brasil. Boletim Museu Paraense Emílio Goeldi, Série Ciências Naturais 2: 45-56.

Costa, J.M. \& Pietrobom. M.R. 2010. Samambaias e licófitas do Parque Ecológico do Gunma, município de Santa Barbara do Pará, estado do Pará, Brasil. Rodriguésia 61: 223-232.

Costa, J.M.; Pietrobom, M.R. \& Souza, M.G.C. 2006. Primeiro registro de Trichomanes pinnatinervium Jenman (Hymenophyllaceae - Monilophyta) para o Brasil. Bradea 11: 33-36.

Cunha, M.F.M. da; Sampaio, A.F.; Frigeri, R.B.C. \& Manzatto, Â.G. 2014. Hymenophyllaceae (Monilophyta) da Estação Ecológica Cuniã, município de Porto Velho, Rondônia. Acta Biológica Catarinense 1: 46-59.

Dubuisson, J-Y; Hennequin, S.; Bary, S.; Ebihara, A. \& Boucheron-Dubuisson, E. 2011. Anatomical diversity and regressive evolution in trichomanoid filmy ferns (Hymenophyllaceae): A phylogenetic approach. Comptes Rendus Biologies 334: 880-895.

Ebihara, A.; Dubuisson, J.; Iwatsuki, K.; Hennequin, S. \& Ito, M. 2006. A taxonomic revision of Hymenophyllaceae. Blumea 51: 1-60.

Fernandes, R.S.; Maciel, S. \& Pietrobom, M.R. 2012. Licófitas e monilófitas das Unidades de
Conservação da Usina Hidroelétrica - UHE de Tucuruí, Pará, Brasil. Hoehnea 39: 247-285.

Ferreira, L.V.; Parolin, P.; Muñoz, S.H. \& Chaves, P.P. 2012. O efeito da fragmentação e isolamento florestal das áreas verdes da Região Metropolitana de Belém. Pesquisas Botânica 63: 357-367.

Goés-Neto, L.A.A. \& Pietrobom, M.R. 2012. Novos registros de samambaias para a Amazônia Brasileira. Rodriguésia 63: 1151-1155.

Hennequin, S.; Ebihara, A.; Ito, M.; Iwatsuki, K. \& Dubuisson, J. 2006. New insights into the phylogeny of the genus Hymenophyllum s.l. (Hymenophyllaceae): revealing the polyphyly of Mecodium. Systematic Botany 31: 271-184.

Hirai, R.Y. \& Prado, J. 2011. Criptógamos do Parque Estadual das Fontes do Ipiranga, São Paulo, SP, Brasil. Pteridophyta: 10. Hymenophyllaceae. Hoehnea 38: 501-510.

IDESP - Instituto de Desenvolvimento Econômico, Social e Ambiental do Pará. 2013. Páginas, produtos, estatística municipal. Disponível em $<$ http://www.idesp.pa.gov.br/paginas/produtos/ estatisticaMunicipal.php>. Acesso em 13 julho 2013.

IPNI - The International Plant Name Index. 2014. Disponível em <http://www.ipni.org/ipni/ plantnamesearchpage.do>. Acesso em 20 julho 2014.

Iwatsuki, K. 1977. Studies in the systematics of filmy ferns III. An observation on the involucres. Botanical Magazine (Tokyo) 90: 259-267.

Lellinger, D.B. 1991. Notes on neotropical Hymenophyllaceae. American Fern Journal 81: 24-37.

Lellinger, D.B. 1994. Hymenophyllaceae. In: Görtsvan Rijn, A.R.A. (ed.). Flora of the Guianas, series B: Ferns and Fern allies: fascicle 3. Hymenophyllaceae. Koeltz Scientific Books, Koenigstein. Pp.1-66.

Maciel, S.; Pietrobom, M.R. \& Souza, M.G. 2007. Licófitas e monilófitas do Bosque Rodrigues Alves Jardim Botânico da Amazônia, município de Belém, Estado do Pará, Brasil. Boletim do Museu Paraense Emílio Goeldi 2: 69-83.

Mickel, J.T. \& Smith, A.R. 2004. The Pteridophytes of Mexico. Vol. 88. Memoirs of the New York Botanical Garden, New York. 1055p.

Morton, C.V. 1968. The genera, subgenera, and sections of the Hymenophyllaceae. Contributions from the United States National Herbarium 38: 153-214.

Pacheco, L. 1995. Hymenophyllaceae. In: Moran, R.C. \& Riba, R. (ed.). Psilotaceae a Salviniaceae. In: Davidse, G.; Sousa, M.; Knapp, S. (ed.). Flora Mesoamericana. Vol.1. Universidad Autonoma de Mexico, Ciudad de Mexico. Pp. 62-83.

Pichi-Sermolli, R.E.G. 1977. Tentamen pteridophytorum genera in taxonomicum ordinem redigendi. Webbia 31: 315-512. 
Pietrobom, M.R.; Barros, I.C.L. 2006. Associações entre as espécies de pteridófitas em dois fragmentos de Floresta Atlântica do Nordeste Brasileiro. Biotemas 19: 15-26.

Pires, J.M. 1973. Os tipos de vegetação que ocorrem na Amazônia. In: Simpósio sobre a Biota Amazônica. Publicações Avulsas do Museu Paraense Emílio Goeldi 20: 179-202.

Pryer, K.M.; Smith, A.R.; Hunt, J.S. \& Dubuisson, J-Y. 2001. $r b c L$ data reveal two monophyletic groups of filmy ferns (Filicopsida: Hymenophyllaceae). American Journal of Botany 88: 1118-1130.

Sehnem, A. 1971. Himenofiláceas. In: R. Reitz (ed.). Flora ilustrada Catarinense. Herbário Barbosa Rodrigues, Itajaí. Pp.1-98.

Smith, A.R. 1995. Hymenophyllaceae. In: Berry, P.E.; Holst, B.K.; Yatskievych, K. (ed.). Flora of the Venezuelan Guayana: Pteridophytes, Spermatophytes (Acanthaceae-Araceae). Timber Press, Portland. Vol. 2, pp. 159-185.

Smith, A.R.; Pryer, K.M.; Schuettpelz, E.; Korall, P.; Schneider, H. \& Wolf, P.G. 2006. A classification for extant ferns. Taxon 55: 705-731.

Thiers, B. 2012. [continuosly update]. Index Herbariorum: A global directory of public herbaria and associate staff. New York Botanical Garden's Virtual Herbarium. Disponível em <http://sweetgum.nybg.org/ih/>. Acesso em 14 outubro 2012.

Tryon, R.M. \& Conant, A.S. 1975. The ferns of Brazilian Amazonia. Acta Amazonica 5: 23-34.

Tryon, R.M. \& Tryon, A.F. 1982. Ferns and allied plants, with special reference to tropical America. Springer-Verlag, New York. 857p.

Windisch, P.G. 1988. Sinopse das espécies do grupo Trichomanes crispum L. (Pteridophyta - Hymenophyllaceae) ocorrentes na Amazônia brasileira. Bradea 5: 55-58.

Windisch, P.G. 1992. Flora da Serra do Cipó, Minas Gerais: Hymenophyllaceae. Boletim de Botânica 13: 133-139.

Windisch, P.G. 1996. Pteridófitas do Estado de Mato Grosso: Hymenophyllaceae. Bradea 6: 400-423.

Windisch, P.G. 2014. Hymenophyllaceae. In: Lista de Espécies da Flora do Brasil. Disponível em <http://floradobrasil.jbrj.gov. br/jabot/floradobrasil/FB91174> . Acesso em 19 dezembro 2014.

Zotz, G. \& Buche, M. 2000. The epiphytic film ferns of a tropical lowland forest - species occurrence and habitat preferences. Ecotropica 6: 203-206.

Zuquim, G.; Costa, F.R.C.; Prado, J. \& Tuomisto, H. 2008. Guia de samambaias e licófitas da REBIO Uatumã, Amazônia Central, Manaus. 316 p. 
